\title{
Bilim Sanat Merkezi Yöneticilerinin Bağlamsal Performansının Sosyal Ağ Analizi Yaklaşımı ile Değerlendirilmesi*
}

\author{
Zeynep EREN**
}

Öz

Bu araştırmada Bilim Sanat Merkezleri'nin (BİLSEM) üst yöneticilerinin bağlamsal performansı, profesyonel destek ağı örüntüleri aracılığıyla açığa çıkarılarak analiz edilmiştir. Nitel ve sosyal ağ analizi yöntemlerinin birlikte kullanıldığı karma araştırma yöntemi ile yürütülen araştırmaya Türkiye genelindeki çeşitli il ve bölgelerde görevli 30 BİLSEM üst düzey yöneticisi destek vermiştir. Araştırmanın verileri 2018 yılında, yarıyapılandırılmış görüşme formu ile çevrimiçi olarak toplanmıștır. Araștırmada yöneticilerin birbirlerinin işlerini kolaylaștırma ve kendilerini geliştirmek için hangi diğer meslektaşlarından hangi konularda destek aldıkları ve profesyonel destek ilişkilerinin geliştirilmesine yönelik önerileri sorulmuş ve profesyonel destek ağı örüntüleri ortaya çıkarılarak sosyal ağ analizine özgü olarak geliştirilen UCINET 6.0 yazılımı ile analiz edilmiştir. Araştırmanın bulgularına göre, yöneticilerden 30 katılımcının profesyonel destek ağı örüntüsü 68 aktörden ve 113 bağlantıdan oluşmuştur. Farklı coğrafi bölgelerde ve birbirinden uzak olmalarına rağmen aralarında profesyonel destek ilișkisi oluştuğu, eğitim değişkenine göre kıdem değişkeninin katılımcılar için profesyonel destek alma açısından daha değerli bulunduğu, üst yöneticilerin maksimum gerçekleştirilecek bağlantının \%25'ini gerçekleștirdiği bulunmuştur.

Anahtar Kelimeler: Performans, Bağlamsal Performans, Yönetici, Sosyal Ağ Analizi, Bilim Sanat Merkezi.

\section{Evaluation of Contextual Performance of Managers of Science Art Center with Social Network Analysis Approach}

\section{Abstract}

In this study, the contextual performance of the senior managers of the Science Art Centers (BILSEM) was analyzed by means of the professional support network patterns. In several provinces and regions qualitative and social network analysis methods to research conducted by mixed research methods being used together across Turkey gave support worker 30 senior manager. The data of the study were collected online in 2018 with semi-structured interview form. In the research, it has been asked about which other colleagues of the managers to support each other in order to improve their work and to

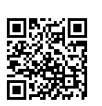

\section{Özgün Araştırma Makalesi (Original Research Article) \\ Geliş/Received: 03.01.2019 \\ Kabul/Accepted: 13.09 .2019}

DOI: https://dx.doi.org/10.17336/igusbd.507287

* Bu çalışma 5-7 Ekim 2018 tarihinde Samsun'da düzenlenen “International Congress on Social \& Legal Studies” kongresinde sözlü bildiri olarak sunulmuş ve bildiri özetleri kitabında özeti yayınlanmıștır.

${ }^{* *}$ Doç. Dr., Sinop Üniversitesi, Eğitim Fakültesi, Eğitim Yönetimi Ana Bilim Dalı, Sinop, Türkiye, E-posta: zugurlu@sinop.edu.tr ORCID ID https://orcid.org/0000-0001-9748-6972 
get support from them for their support and to develop professional support network patterns and analyze them with UCINET 6.0 software for developed spesific social network analysis. According to the findings of the research, the professional support networks of the 30 managers are composed of 68 actors and 113 links. 25\% of the maximum connection is realized. Although they are distant from each other in different geographical regions and there is a professional support relationship between them, it is found that the seniority variable is more valuable in terms of getting professional support for the participants according to the educational variable.

Keywords: Performance, Contextual Performance, Manager, Social Network Analysis, Science Arts Centre.

\section{Giriş}

Üstün veya özel yetenekli bireyler doğru yapılandırılmış bir eğitimle insanlık tarihi için önemli işlere imza atabilecek potansiyele sahiptirler. Bu potansiyelin doğru biçimde işe koşulması ve geliștirilmesi, uygun ortam ve koşulların sağlanmasına bağlıdır. Türkiye'de üstün yetenekli öğrenciler, Bilim Sanat Merkezleri (BİLSEM) olarak adlandırılan kurumlar aracılığı ile desteklenmektedir. Bu kurumlar, 1995 yılından itibaren Milli Eğitim Bakanlığı (MEB) bünyesinde okulöncesi, ilköğretim ve ortaöğretim düzeyindeki üstün yetenekli öğrencilerin örgün eğitim dışında ilgi ve yetenekleri doğrultusunda geliştirmelerine destek olmak amacıyla kurulmuştur (Kaya, 2013; Kılıç, 2015). BİLSEM'lerde proje tabanlı ve farklı eğitim öğretim teknikleri kullanılarak üstün ve özel yetenekli öğrencilere eğitim-öğretim etkinlikleri desteği vermektedir. Bu yönü ile BİLSEM’ler okul gibi işlev yürütmekle birlikte, okullardan farklı bir işleyișe sahiptirler.

BİLSEM yönergesine (2016) göre, bu kurumlardan eğitim desteği almaya hak kazanmak için öğrenciler, MEB'in her yıl ilan ettiği belirli takvimlerde Rehberlik Araştırma Merkezleri (RAM) psikolojik danışmanları ve diğer uzmanlar tarafından bilgi ve yetenek sınavları, çeşitli yetenek ve psikoloji testleri kullanılarak taramadan geçirilmektedir. Tarama sonrası üstün ya da özel yetenekli öğrenci tanısı konulur ve bu öğrenciler BİLSEM'lerden destek almaya ve bu kurumlarda düzenlenen teknoloji, projelere katılım, sanat, kod yazma ve robotik, fen ve sosyal bilimler kuramsal ders desteği gibi çok çeşitli konularda gerçekleștirilen eğitim faaliyetlerinden yararlanmaya hak kazanırlar. Aynı biçimde öğretmen ve yöneticilerin görevlendirilmesinde de sınav ve başvuru süreçleri MEB'deki diğer öğretmen ve yönetici görevlendirmelerinden ayrı takvim ve yönergeler doğrultusunda işletilmektedir. Özetle BİLSEM'ler kendileri için özel olarak oluşturulmuş olan işleyiş ve mevzuat çerçevesinde yaşamını sürdüren, MEB bürokrasisine bağlı yönleri olmakla birlikte diğer örgün eğitim kurumlarından farklı, kısmen okul gibi çalışan, okul dışı zamanlarda öğrenciler yararlandığı için esnek çalışma saatleri ile işleyişlerini sürdüren kendine özgü kurumlardır.

MEB'in 2018 yılı istatistiklerine göre bu merkezlerde hali hazırda yaklaşık 2000 öğretmen görev yapmakta ve 37500 üstün yetenekli olarak tanılanmış öğrenci, yetenekleri doğrultusunda eğitim desteği almaktadır. 2017-2018 eğitim-öğretim yllı itibariyle, 81 ilde toplam 133 BİLSEM aktif durumdadır. Türkiye'de üstün yetenekli öğrencilerin tümü henüz bu eğitimden yararlanamamakla ve BİLSEM'lerin işleyişi konusunda çeşitli sorunlar yaşanmaktadır. Üstün yetenekli öğrencilere özgü eğitim politikalarının yetersizliği ya da oluşturulmaması, alt yapı ve donanım yetersizliği, üniversiteler ve TÜBITTAK gibi kurumlarla yeterince işbirliği içinde çalışılmaması, öğretmen ve yöneticilerinin nicelik ve nitelik olarak yetersiz olması, özel eğitime ayrılan bütçenin çoğunun alt zekâ gruplarına aktarılırken, sadece binde birlik kısmının üst zekâ gruplarına aktarılması ve üstün yetenekli öğrencilerin sayısı genel olarak toplam öğrenci 
sayısının \%2'si olarak öngörülmesine rağmen ülkemizde ancak binde bir oranında bu özelliklere sahip öğrenci tespit edilebilmesi öncelikli sorunlar olarak sayılabilir (Altun \& Vural, 2012; Kaya, 2013; Kazu \& Şenol, 2012; Kılıç, 2015; Kurtdaş, 2012; Sarı \& Ögülmüș, 2014; Şahin, 2012; Yumuş \& Toptaş, 2011). “Üstün Yetenekli Çocukların Keşfi, Eğitimleriyle İlgili Sorunların Tespiti ve Ülkemizin Gelişimine Katkı Sağlayacak Etkin İstihdamlarının Sağlanması Amacıyla Kurulan Meclis Araștırması Komisyonu" (5 Nisan 2012) nun çalışmalarına ilişkin düzenlenen raporda aynı sorunlara dikkat çekilmiștir. Raporda "bunca soruna rağmen hala BILSEM'lerden memnuniyetin bu kurumlardaki öğretmen ve idarecilerin kişisel çabalarıyla ortaya çıktığı" saptamasında bulunulmuștur. Tüm bu sorunlara rağmen üstün yetenekli öğrenciler için özel kurumlar olușturulması girișimi, bu kurumlarda çalışanların özverili çalışmaları MEB'in ve eğitim sistemimizin aydınlık yüzü olarak değerlendirilebilir.

Üstün yetenekli bireylerin eğitimlerinin etkili bir şekilde gerçekleştirilebilmesi için bu bireylere sağlanacak öğrenme ortamlarının, programın ve öğretmenlerin normal öğrencilerden farklı ve daha üst seviyede becerilere hitap edecek șekilde yapılandırılması gerekmektedir (Abraham, 1982; Renzulli, 1978; Sternberg, Jarvin \& Grigorenko, 2011; Şahin, 2012; Tomlinson \& Callahan, 1992; Winebrenner, 2000). Bu kurumların etkili ve verimli çalıştırılması, üstün yetenekli bireylere sağlayacağı faydayı artıracaktır. $\mathrm{Bu}$ konudaki temel görev, eğitimle ilgili kararları alanlar, stratejileri belirleyenler kadar bu kurumlardaki yöneticilere de düşmektedir.

Bir örgütün bașarısı, örgütte çalışanların performansından ayrı düşünülemez. Performans değerlendirme, örgütteki çalışanların örgütün amaçlarına uygun olarak ortaya koydukları eylem ve davranışlarının örgüte olan katkısının ölçümüdür (Daft, 1997). Bu nedenle, hangi alanda ve hangi tür örgütlerde olursa olsun örgütlerin verimliliğini artırmak için çalışanların verimliliği ve performansı ve buna bağlı olarak performans değerlendirme yaklaşımları, yönetim ve insan kaynakları alanlarının başlıca çalıșma konularından birisini olușturmaktadır.

\section{Performans Değerlendirme ve Bağlamsal Performans}

İş ya da performans değerlendirme dendiği zaman, çalışanların örgüt içindeki etkinliklerinin yönetici açısından analizinin yapılması ve kişiden istenenin ne ölçüde gerçekleştiğinin saptanması akla gelmektedir (Aydın, 2005, s. 146). Örgüt alan yazınında performans kavramı görevsel performans (task performance) ve bağlamsal performanstan (contextual performance) oluşan çok boyutlu bir kavram olarak ele alınmaktadır. Görev performansı, bir ișin diğer bașka ișlerden ayrıșmasını sağlayan sabit görev ve sorumluluklar olarak açlklanmaktadır (Jawahar \& Ferris, 2011) ve işin tamamlanmasıyla ilgilidir. Görev performansının içerdiği davranışlar örgütlerin teknik temel yeteneklerine katkı sağlar (Borman \& Motowidlo, 1993). Bağlamsal performans ise, görev ya da hedefe özgü olmayan, ancak bireyleri, takımları ve örgütleri daha etkili ve bașarılı kılan aktiviteleri ifade eder (Reilly \& Aronson, 2012).

Örgütlerde çalışanların sadece bireysel özellikleri değil diğer çalışanlarla ilişkilerini sürdürüş biçimleri de önemli bir yer tutmaktadır. Bağlamsal performans kavramının karakteristik özelliği, kişiler arası sosyal ilişkiler ve diğer insanlarla destekleyici bir yapı oluşturulmasına dayanmaktadır. Organ’a (1997) göre, bağlamsal performans, bir çalışanın görev tanımında olmamasına rağmen diğer çalışma arkadaşlarına yardım etmesi ve onlarla ișbirliği yapmaya gönüllü olmasıdır. Scotter ve Motowidlo'ya (1996) göre bağlamsal performans, kişilerarası kolaylaştırıcılık ve ișe adanmayı içerir. Kişilerarası kolaylaştırıcılık, çalışma arkadaşlarının performanslarını da destekleyen, anlayışlı, işbirliği içinde çalışmaya yatkın, yardımsever eylemlerden oluşur. İșe adanma ise, çalışanların içsel bir disiplin ile örülmüş ve motive olmuş bir biçimde çok 
çalışması, inisiyatif alması ve belirlenen hedeflere ulaşmak için kurallara uyması gibi eylemleri içerir.

Bağlamsal performans, özellikle ekiplerde ve takım çalışmalarında daha kritik bir önem taşımaktadır (Morgeson, Reider \& Campion, 2005). Alan yazında bağlamsal performansın ölçülmesi için geliștirilen ölçekler incelendiğinde, Coleman ve Borman (2000), Greenslade ve Jimmieson (2007), ülkemizde ise Aslan ve Yıldırım (2017) gibi araştırmacılar tarafından geliştirilen ölçeklere rastlanmaktadır. Kullanılan ölçekler genel olarak incelendiğinde, bağlamsal performansın kişilik özellikleri, toplumsal ve örgütsel kültür ve liderlik boyutlarında ölçüldüğü görülmektedir. Tablo 1'de görülen Borman ve Modowidlo (1993) tarafindan oluşturulan bağlamsal performans taksonomisine göre, bağlamsal davranışlar kendi görevini coşku ve fazladan çaba ile tamamlamak, kendini örgütün bir parçası olarak görerek gönüllü çalışmak, diğerlerine yardımcı olma ve işbirliği, örgütsel kural ve prosedürlere uygun davranmak ve örgütsel hedefleri savunmak ve desteklemek başlıkları altında toplanmıştır.

\begin{tabular}{|c|c|c|}
\hline Boyut & Ölçüt & Kullanılan Göstergeler \\
\hline 1 & $\begin{array}{l}\text { Kendi görev faaliyetlerini } \\
\text { başarıyla tamamlamak } \\
\text { için gerekli olan coşku ve } \\
\text { ekstra çaba ile devam } \\
\text { etmek. }\end{array}$ & $\begin{array}{l}\text {-Azim ve vicdanlllık /dürüstlük (Bonnan vd., 1985) } \\
\text {-i̇ş için fazladan çaba sergileme (Brief \& Motowidlo, } \\
\text { 1986; Katz \& Kahn, 1978) }\end{array}$ \\
\hline 2 & $\begin{array}{l}\text { Kendi işinin resmi bir } \\
\text { parçası olmayan görev } \\
\text { faaliyetlerini yürütmek } \\
\text { için gönüllülük. }\end{array}$ & $\begin{array}{l}\text {-Örgütsel iyileştirmeler önerme (Brief \& Motowidlo, } \\
\text { 1986; Kaa \& Kahn, 1978) } \\
\text {-Ekstra sorumluluk alma ve girişkenlik (Bornran vd., } \\
\text { 1985; Brief \& Motowidlo, 1986; Katz \& Kahn, 1978) } \\
\text {-Yapıcı önerilerde bulunmak (George \& Brief, 1992) } \\
\text {-Kendini geliștirme (George \& Brief, 1992) }\end{array}$ \\
\hline 3 & $\begin{array}{l}\text { Diğerlerine yardımcı } \\
\text { olma ve işbirliği }\end{array}$ & $\begin{array}{l}\text {-İş arkadaşlarına yardım etme (Borman vd., 1985; Brief } \\
\text { \& Motowidlo, 1986; Katz \& Kahn, 1978) } \\
\text {-Müssterilere yardım etme (Brief \& Motowidlo, 1986) } \\
\text {-Örgütsel nezaket (Organ, 1988) } \\
\text {-Sportmenlik (Organ, 1988) } \\
\text {-Alturizm / Diğergamlık (Smith vd., 1983) }\end{array}$ \\
\hline 4 & $\begin{array}{l}\text { Örgütsel kural ve } \\
\text { prosedürleri izleme / } \\
\text { uygun davranma }\end{array}$ & $\begin{array}{l}\text {-Otoriteye saygı ve kural ve prosedürleri izleme (Born } \\
\text { vd., 1985) } \\
\text {-Örgütsel değerlere ve politikalara uyma (Brief \& } \\
\text { Motowidlo, 1986) } \\
\text {-Dürüstlük (Smith vd., 1983) } \\
\text {-Kisa toplantılar(Katz \& Kahn, 1978) } \\
\text {-Toplumsal erdem (Graham, 1986) }\end{array}$ \\
\hline 5 & $\begin{array}{l}\text { Örgütsel hedefleri } \\
\text { savunmak ve } \\
\text { desteklemek, onaylamak }\end{array}$ & $\begin{array}{l}\text {-Örgütsel sadakat (Graham, 1986) } \\
\text {-Birimin hedefleri ile ilgilenmek, endişelenmek } \\
\text { (Borman vd., 1985) } \\
\text {-Zor zamanlarda örgütte kalmak ve örgütü yabancılara } \\
\text { karşı olumlu biçimde temsil etmek (Brief \& Motowidlo, } \\
\text { 1986) } \\
\text {-Örgüte sahip çlkmak, korumak (George \& Brief, 1992) }\end{array}$ \\
\hline
\end{tabular}

Tablo 1. Borman ve Motowidlo'nun (1993) Bağlamsal Performans Taksonomisi

Borman ve Motowidlo (1993) tarafından geliștirilen ve Tablo 1'de verilen bağlamsal performans taksonomisinde görüldüğü gibi, beş boyutta belirlenen ölçütler farklı araştırmacılar tarafından yapılan araștırmalarda da kullanılmıștır. Bağlamsal performans ve örgütsel vatandaşlık kavramları oldukça örtüșen ve hatta zaman zaman birbirinin yerine kullanılan kavramlardır. Smith, Organ ve Near (1983) tarafindan 
geliştirilen on maddelik ölçekte bağlamsal performansın çoklukla kavramlarını ödünç aldığı örgütsel vatandaşlık davranışı ölçülmektedir. Aynı biçimde Podsakoff ve MacKenzie (1994), Sharma ve Jain (2014) gibi araştırmacılar, bu iki kavramı birbirinin yerine kullanmışlardır. Bunun dışında sosyal örgüt davranışları, rol fazlası davranışlar, örgütsel spontanlık, sivil örgütsel davranışlar olarak da adlandırıldığı görülmektedir (Reilly \& Aronson, 2012, s.33). Bahsedilen kavramların ortak özelliği, örgütte görev tanımının üstünde psikolojik, sosyal ve gönüllü davranışları içermesidir. Kavramlar incelendiğinde çalışanın görevini yaparken kendisinden beklenenden fazlasını vermesini içeren bu davranışların kökeninin daha gerilere uzandığı görülebilir. Turnipseed ve Murkison (2000), bu kavramın kökeninin örgütte çalışanların enerjilerini örgüt adına harcarken istekli olmaları gerektiğini vurgulayan Barnard (1938) ve bunun koşullarını sağlamak üzere yapılan Hawthorne Araștırmaları'na ve insan ilișkileri ekolüne kadar uzanabileceğini belirtmiştir. Bağlamsal davranıșların ölçülmesi ve geliștirilmesine yönelen temel ilginin nedeni bu tür bağlamsal davranışların örgütsel verimliliği artırmasıdır (Podsakoff \& MacKenzie, 1994). Bağlamsal performans kavramı, çalışanların performansının değerlendirilmesinde, çalışma davranışlarının bu yönünün de değerlendirilmesine ilişkin ihtiyaçtan doğmuștur.

Görev performansının ölçümünde çalışanların önceden tanımlanmış görev davranışlarını ne oranda yerine getirdiği ölçülmektedir. Ancak görev performansının ölçüm kolaylığının aksine bağlamsal davranışları ölçmek nispeten karmaşıktır. Çünkü bağlamsal davranıșlar çalışanların sadece bireysel davranışlarına değil örgütteki çok değișik faktörlere bağlıdır. Bağlamsal performansla ilgili araştırmalar incelendiğinde, bireysel ve örgütsel performans, çalışanların kişilik özellikleri, güven, iş tutumları ve örgütsel değiş̧kenler, yaș, akademik performans, örgütsel bağlılık, iş doyumu ve değerler, örgütsel öğrenme gibi değişkenler ve konular üzerinde çalışıldığı görülmektedir (Allison, Voss \& Dryer, 2001; Deluga, 1994; Feather \& Rauter, 2004; Organ \& Lingl,1995; Penner, Midili \& Kegelmeyer, 1997; Somech \& Drach-Zahavy, 2004; Wagner \& Rush, 2000, Akt: Jawahar \& Ferris, 2011).

Bağlamsal performansın ölçümünde kullanılan geleneksel yaklaşımlar insan kaynakları yönetiminde kullanılan bireyi odağa alan ve örgüt özellikleri ve bireysel özelliklerin eşleştirilmesi, karşılaştırılması ve uyumlaştırılmasını içeren klasik yaklaşımların bir yansıması olarak düşünülebilir. Oysa bağlamsal davranışlar büyük ölçüde örgütteki biçimsel olmayan ilişkilere dayanmaktadır (Eren, 2018). Krackhardt ve Hanson'a (1993) göre, yöneticiler, geleneksel yaklaşımlar yerine ağ yaklaşımını kullanarak, biçimsel olmayan ilişkilerin nasıl işlediğini gösteren ilişki ağlarını ortaya koyarak haritalayabilirler. Dolayısıyla bu davranışların grup dinamiği süreçleri içinde incelenmesinde ağ yaklașımının farklı bir bakıș açısı getirme potansiyeli vardır.

\section{Sosyal Ă̆ Yaklaşımının Bağlamsal Performansın Değerlendirilmesinde Kullanılma Potansiyeli}

Ağ teorisi, bir toplumsal yapıyı araştırmanın en doğru yolunun üyelerin birbiri ile ilişkisini oluşturan bağların örüntüsünü çözümlemek olduğu temel varsayımına dayanmaktadır (Wellman, 1988). Ağ kuramı, ağı oluşturan aktörler arasındaki ilişkilerin özelliklerinden çok ilişkilerin yapısını inceleyen bir kuramdır (Wasserman \& Faust, 1994, akt: Uğurlu, 2013). Ağ araștırmalarında örgütler, ülkeler, birimler, bölümler gibi canlı ve cansız varlıklar arasındaki yapısal ilişkiler analiz edilebilir. İnsanlar tarafından oluşturulan başka bir ifade ile aktörleri insanlar olan ya da insanlar arası betimlenmiş bir iliş̧inin incelendiği ağlar ise sosyal ağlar olarak adlandırılır.

Sosyal bilimlerde kullanılan sosyal ağ kavramı, iyi tanımlanmış gruplardaki aktörler arasındaki bağlantılardan oluşan ilişki örüntüleridir (Scott, 2000; Sözen, 2012). 
Bir sosyal ağı oluşturan üç ana unsur aktörler (actors, node), aktörlerin birbirleriyle olan ilişkileri (edge, vertex) ve bu ilişki örüntüsünün farklı etkileşimleriyle ortaya çıkardığı yapıdır. Bu ilişki örüntüleri, sosyal ağ kuramının kendine has araştırma yaklaşımları ile analiz edilebilmektedir. Sosyal ağ analizi, karmaşık işbirliği ilişkilerini ortaya koymadaki üstünlükleri nedeniyle yeni bir araștırma yaklaşımı olarak dikkat çekmektedir (Öztaş \& Acar, 2004).

Sosyal ağ analizinin diğer yöntemlerden temel farklılığı, sosyal varlıklar arasındaki ilişkiler ve bu ilişki modellerine odaklanmasıdır. Sosyal ağ analizi, bireysel davranışlar, tutumlar ve inançlar yerine aktörlerin diğer aktörler ile etkileşimine ve bu etkileşimin nasıl bir çerçeve ya da yapı oluşturduğuna odaklanmaktadır. Açıklanan bu özellikler sosyal ağ analizini diğer araştırma yaklaşımlarından farklılaştırmaktadır (Wasserman \& Galaskiewicz, 1994).

Ağ araştırmalarını geleneksel yaklaşımlardan ayıran bazı ayırt edici özellikler șunlardır: (Kiduff \& Tsai, 2007): (1) Ağ araștırması, aktörlerin niteliklerine değil, ilișkilere ve ilişki kalıplarına odaklanır. (2) Ağ araștırması çoklu analiz seviyelerine uygundur ve bu nedenle mikro makro bağlantılarını sağlayabilir. (3) Ağ araştırması, nicel, nitel ve grafiksel verileri bütünleştirerek daha kapsamlı ve derinlemesine analizlere olanak sağlar. Bu özelliklerin hiçbiri sosyal bilimlerdeki geleneksel yaklaşımlarda iyi bir şekilde kurulmamıştır. Burt'ın (1992) belirttiği gibi, sosyal ağ analizi, sosyal kuramın mikro ve makro düzeylerini birleştirme potansiyeli taşıyan güçlü bir metodolojidir.

Örgüt analizinde sosyal ă̆ araştırmalarının kullanım alanı oldukça geniştir (Kilduff \& Tsai, 2007). Bunun temel nedeni, çoklu ilişkilerin değerlendirilmesine olanak sağlayan bu yaklaşımın, karmaşık ve tekrarlı ilişki örüntülerinin ortaya çıkarılmasına getirdiği yeni bakış açısı ve üstünlüklerdir (Öztaş \& Acar, 2004). Bu durum, sosyal ağ analizi yönteminin kullanıldığı çeşitli araştırmalarla da ortaya konulmuştur: Mehra, Kilduff, ve Brass (2001), kişilik özellikleri ile performans arasındaki ilișkiyi araştırmıștır. Araştırma bulgularına göre benlik algısı yüksek çalışanların sosyal ağlardaki yapısal konumlarına göre daha iyi performans sergiledikleri, bu çalışanların çatışmalarını uzlaşı ve işbirliği ile çözme eğiliminde oldukları, grupların liderlerinin de bu çalışanlar arasından çıkma olasılığının daha yüksek olduğu bulunmuştur. Sparrowe, Liden, Wayne ve Kraimer (2001), hem olumlu hem de olumsuz ilişkiler açısından tanımlanan sosyal ağların hem bireysel hem de grup performansıyla ilişkili olduğu bulgusuna ulaşmıştır. Tsai (2001) tarafından yapılan araștırmada inovasyon sürecinde bilgi paylașımı ağlarında merkezîlik ve yüksek performans arasında pozitif bir ilişki bulunmuştur. Cummings ve Cross (2003), örgütte grubun performansı ile kişilerarası iletişim ağı arasında pozitif yönde bir ilișki bulmuştur. Reagans, Zuckerman ve McEvily (2004), ekiplerin performansını çalışanların sosyal yapı içindeki ağ içindeki konumları ve ağ yapısal özellikleri ve çalışanların demografik özellikleri açısından karşılaștırarak araștırmıştır. Performansı yüksek olan ekiplerin bilgi paylaşımı ağlarının yoğunluğunun yüksek olduğunu bulmuştur. Shaw, Duffy, Johnson ve Lockhart (2005), tarafindan yapılan araștırmada, çalışanların iletişim ağında merkezîlik dereceleri yüksek olanların ve yoğunluğu yüksek olan ekiplerin satış performansları daha yüksek bulunmuştur. Balkundi ve Harrison, (2006), ekip içi ve ekipler arası çalışma ağlarında ekip performansı ile yoğunluk ve merkezîlik arasında olumlu bir ilişki bulmuştur. Yoğunluğu yüksek ekiplerin ve merkezîlik derecesi yüksek aktörlerin performansı daha fazladır. Sarkar, Fienberg ve Krackhardt (2010), kârlılık oranları ile danıșmanlık ağları arasındaki ilișkiyi incelemiştir. Araştırmada kârlılık oranı daha yüksek olan şubelerin ağ içinde daha merkezi konumda yer aldığı bulunmuştur. Soda ve Zaheer (2012), biçimsel olamayan ilişki yapısı olarak tanımlanan öneri arayışı ile çalışanların iş akışları ve kural ve prosedürler olarak tanımlanan biçimsel yapı arasında bireysel performans açısından pozitif yönde tutarlı bir ilişki bulmuştur. Hunter'a (2015) göre örgütte biçimsel ve 
biçimsel olmayan yapıların analizinde biçimsel olmayan ilişkilerin örgütsel performans için ilişkilerde yol-mesafeyi azaltıcı etkisi olumlu bir etkisi vardır. Ancak bu ilişkiyi doğrudan test eden daha fazla deneysel araştırma gereklidir.

Türkiye'de hem sosyal ağ analizi hem de sosyal ağ analizi ile çalışanların performansını değerlendirme üzerine yapılan araștırmalar son derece kısıtlıdır. Başak ve Öztaş (2010) tarafından sosyal ağ analizi kullanılarak yapılan araştırmada, sosyal sermaye ile toplumsal cinsiyet, sınıf ve örgüt temelinde yapılan analizlerde cinsiyetten bağımsız olarak yönetici konumunda olanların sosyal sermayesi daha alt konumlarda çalışanlara oranla daha yüksek bulunmuştur. Kapusuzoğlu ve Uğurlu'nun (2015) işbirliğinin maliyetlerinin araştırıldığı çalışmada katılımcıların günlük çalışmalarında en çok zaman alan, çalışmalarını zorlaştıran ve bilgilendirici değeri taşımayan görüșmelerin daha fazla olduğu ve bunun gereksiz iş yükü ve darboğazlar yarattığı bulunmuştur. Kahraman, Sözen ve Meydan'ın (2018) araştırmasında bireylerin ağ düzeneğindeki yerinin oluşmasında lider-üye etkileşiminin rolü, sosyal ağ analizi yaklaşımı ile incelenmiştir. Analizler sonucunda liderin merkezde olduğu, lider - üye etkileşiminin kalitesinin aktörün merkeziliğini yordadığı, ancak bu süreçte üyelik süresinin önemli bir belirleyici olduğu belirlenmiştir. Eren'in (2018) biçimsel ve biçimsel olmayan örgüt yapılarını karşılaștırmalı olarak incelediği araștırmada atanmış yöneticilerin ağ içinde lider pozisyonunda olmayabileceği ampirik bulguları ile ortaya konulmuştur.

Buraya kadar özetlenen çeşitli araștırmalardan da anlaşılacağı gibi, sosyal ağ analizi, örgütlerde performansı etkileyen faktörlerin ortaya çıkarılmasında, örgütteki çalışanlar arası ilişkilerin yapısal özelliklerini, aktörlerin ilişkilerinin olușturduğu yapı içindeki konumlarını ve bunun performans, güven, sosyal sermaye, örgüt kültürü, liderlik gibi değişkenlerle ilişkilerini kendisine has ölçümleri (merkezilik, yoğunluk gibi) kullanarak derinlemesine anlamayı sağlayan bulgular ortaya koymuştur. Örgütlerde ișin etkin ve verimli bir biçimde yürütülmesi ve işbirliği içinde ekip çalışması ile sürdürülmesinde kişilerarası destek ve yardımcı davranışlar olarak açıklanan bağlamsal davranışların sosyal ağ analizi ile değerlendirilebileceği araștırma bulguları ile de ortaya konmaktadır.

\section{Araştırmanın Amacı}

$\mathrm{Bu}$ araştırmanın temel amacı Bilim Sanat Merkezleri (BILSEM) yöneticilerinin bağlamsal performansını yöneticiler arasındaki profesyonel destek ağı aracılığı ile ortaya koymaktır. Bu temel amaç doğrultusunda aşağıdaki alt sorulara yanıt aranmıştır:

BİLSEM yöneticilerinin mesleki konularla ilgili etkileşimlerinde profesyonel destek ağları nasıldır?

BİLSEM yöneticilerinin profesyonel destek ağının örüntüsü nasıldır?

BİLSEM profesyonel destek ağının etkinlik düzeyi nasıldır?

BILLSEM profesyonel destek ağına katılım ve gruplaşmalar nasıldır?

BİLSEM profesyonel destek ağını oluşturan temel aktörler arası ilişkiler nasıldır?

\section{Yöntem}

\section{Araştırmanın Deseni}

Araştırma sosyal ağ analizi ve nitel araştırmanın birlikte kullanıldığı karma araștırma yöntemiyle yürütülmüștür. Sosyal ağ analizi (social network analysis); aktörler arası ilişkilerin ortaya çıkarılmasında kendisine has ölçümlere sahip disiplinler arası bir araştırma yaklaşımıdır. Aktörler ve aktörler arası ilişkilerin ve bu ilişkilerin oluşturduğu yapının sayısallaştırılarak ya da grafik halinde ortaya çıkarılmasını sağlar (Borgatti, Everett \& Johnson, 2013; Öztaş \& Acar, 2004; Scott, 2000). Freeman’a (2004) göre şu 
özellikler tüm modern sosyal ağ analizi örneklerinde yer alır: Sosyal ağ analizi, toplumsal aktörleri birbirine bağlayan yapısal bağlar hakkında sezgileri gerekçelendirir. Bu deneysel veri, sistematik olarak toplanır ve kontrollüdür. Bu veri grafiklerle sunulur. $\mathrm{Bu}$ hesaplamaların yapılmasında matematiksel modellere güvenilir.

\section{Çalışma Grubu}

Araştırmanın çalışma grubu, 2018 yılında, Bilim Sanat Merkezlerinde (BİLSEM) görevli olan 30 üst yöneticiden oluşmuştur. Araștırmanın örneklemi kartopu örnekleme yöntemiyle belirlenmiștir (Kilduff \& Tsai, 2007). Araştırmaya katılan 30 yönetici profesyonel destek ağına 38 yeni aktör eklemiştir. Dolayısıyla araștırmanın katılımcı sayısı 30, toplam aktör sayısı 68 olarak gerçekleșmiștir. Temel aktörlerin cinsiyet, eğitim, kıdem ve tüm aktörlerin coğrafi bölgeler gibi demografik değişkenlere göre dağılımı Tablo 2'de verilmiştir.

\begin{tabular}{|c|c|c|c|c|}
\hline \multicolumn{2}{|c|}{ Değișken } & $N$ & $\%$ & Aktörler \\
\hline \multirow{3}{*}{ Cinsiyet } & Kadın & 3 & 10 & BSM_01, BSM_08, BSM_12 \\
\hline & Erkek & 27 & 90 & $\begin{array}{l}\text { Yukarıdakilerin dışında kalanların } \\
\text { tümü }\end{array}$ \\
\hline & Toplam & 30 & 100 & \\
\hline \multirow[t]{4}{*}{ Eğitim } & Lisans & 11 & 37 & $\begin{array}{l}\text { BSM_04, BSM_05, BSM_06, BSM_12, } \\
\text { BSM_16, BSM_17, BSM_20, BSM_25, } \\
\text { BSM_26, BSM_27, BSM_29. }\end{array}$ \\
\hline & Yüksek Lisans & 15 & 50 & $\begin{array}{l}\text { BSM_01, BSM_02, BSM_03, BSM_08, } \\
\text { BSM_09, BSM_10, BSM_11, BSM_18, } \\
\text { BSM_19, BSM_21, BSM_22, BSM_23, } \\
\text { BSM_24, BSM_28, BSM_30. }\end{array}$ \\
\hline & Doktora & 4 & 13 & BSM_07, BSM_13, BSM_14, BSM_15 \\
\hline & Toplam & 30 & 100 & \\
\hline \multirow{5}{*}{$\begin{array}{l}\text { Kidem } \\
\text { (Bilsem } \\
\text { Yönetici) }\end{array}$} & Belirtilmemiș & 1 & 3 & BSM_02 \\
\hline & 1 yıl ve daha az & 6 & 20 & $\begin{array}{l}\text { BSM_01, BSM_06, BSM_11, BSM_12, } \\
\text { BSM_20, BSM_26 }\end{array}$ \\
\hline & $1-5$ yil & 14 & 47 & $\begin{array}{l}\text { BSM_03, BSM_04, BSM_05, BSM_10, } \\
\text { BSM_14, BSM_15, BSM_16, BSM_19, } \\
\text { BSM_21, BSM_22, BSM_23, BSM_24, } \\
\text { BSM_27, BSM_28 }\end{array}$ \\
\hline & 5 yll ve daha fazla & 9 & 30 & $\begin{array}{l}\text { BSM_07, BSM_08, BSM_09, BSM_13, } \\
\text { BSM_17, BSM_18, BSM_25, BSM_29, } \\
\text { BSM_30 }\end{array}$ \\
\hline & Toplam & 30 & 100 & \\
\hline \multirow{8}{*}{$\begin{array}{l}\text { Coğrafi } \\
\text { Bölge } \\
\text { Temel } \\
\text { Aktörler }\end{array}$} & Marmara Bölgesi & 6 & 20 & $\begin{array}{l}\text { BSM_08, BSM_11, BSM_12, BSM_23, } \\
\text { BSM_25, BSM_29 }\end{array}$ \\
\hline & Karadeniz Bölgesi & 6 & 20 & $\begin{array}{l}\text { BSM_09, BSM_15, BSM_16, BSM_17, } \\
\text { BSM_21, BSM_30 }\end{array}$ \\
\hline & İç Anadolu Bölgesi & 5 & 17 & $\begin{array}{l}\text { BSM_18, BSM_19, BSM_22, BSM_26, } \\
\text { BSM_27 }\end{array}$ \\
\hline & Akdeniz Bölgesi & 4 & 13 & BSM_01, BSM_03, BSM_10, BSM_24 \\
\hline & Ege Bölgesi & 3 & 10 & BSM_06, BSM_07, BSM_28 \\
\hline & Doğu Anadolu Bölgesi & 3 & 10 & BSM_02, BSM_05, BSM_14 \\
\hline & $\begin{array}{l}\text { Güneydoğu Anadolu } \\
\text { Bölgesi }\end{array}$ & 3 & 10 & BSM_04, BSM_13, BSM_20 \\
\hline & Toplam & 30 & 100 & \\
\hline
\end{tabular}


Zeynep Eren, "Bilim Sanat Merkezi Yöneticilerinin Bağlamsal Performansının Sosyal Ağ Analizi Yaklaşımı ile Değerlendirilmesi”, İstanbul Gelişim Üniversitesi Sosyal Bilimler Dergisi, 7 (1), Nisan 2020, ss. 50-73.

\begin{tabular}{|c|c|c|c|c|}
\hline \multirow{8}{*}{$\begin{array}{l}\text { Coğrafi } \\
\text { Bölge } \\
\text { Eklenen } \\
\text { Aktörler }\end{array}$} & Marmara Bölgesi & 12 & 32 & $\begin{array}{l}\text { BSM_41, BSM_42, BSM_43, BSM_44, } \\
\text { BSM_45, BSM_46, BSM_47, BSM_48, } \\
\text { BSM_51, BSM_61, BSM_62, BSM_63 }\end{array}$ \\
\hline & Karadeniz Bölgesi & 9 & 24 & $\begin{array}{l}\text { BSM_31, BSM_38, BSM_54, BSM_55, } \\
\text { BSM_56, BSM_57, BSM_58, BSM_60, } \\
\text { BSM_68. }\end{array}$ \\
\hline & İç Anadolu Bölgesi & 3 & 8 & BSM_52, BSM_64, BSM_65 \\
\hline & Akdeniz Bölgesi & 5 & 13 & $\begin{array}{l}\text { BSM_32, BSM_33, BSM_34, BSM_49, } \\
\text { BSM_50 }\end{array}$ \\
\hline & Ege Bölgesi & 4 & 11 & BSM_40, BSM_59, BSM_66, BSM_67 \\
\hline & Doğu Anadolu Bölgesi & 1 & 3 & BSM_39 \\
\hline & Güneydoğu Anadolu B. & 4 & 11 & BSM_35, BSM_36, BSM_37, BSM_53 \\
\hline & Toplam & 38 & 100 & BSM_31-BSM_68 arası aktörler \\
\hline \multicolumn{2}{|c|}{ Nitel Araștırma Katılımcı Toplamı } & 30 & 100 & BSM_1-BSM_30 arası aktörler \\
\hline \multicolumn{2}{|c|}{ Sosyal Ağ Analizi Aktör Toplamı } & 68 & 100 & BSM_1-BSM_68 arası aktörler \\
\hline
\end{tabular}

Tablo 2. Katılımcıların Demografik Özellikleri ve Aktörler

Tablo 2'de görüldüğü gibi, 30 katılımcının \%10'u kadın, \%90'ı erkektir. \%37'si lisans, \%50'si yüksek lisans, \%13'ü doktora mezunudur. \%47'si 1-5 yıl arası, \%30'u 5 yıl ve daha fazla süredir, \%20'si 1 yıl ve daha az süredir BİLSEM'de yöneticilik yapmaktadır. Her ikisi de \%20'şer olmak üzere Marmara ve Karadeniz, \%17'si İç Anadolu, \%13'ü Akdeniz ve \%10'ar Ege, Doğu Anadolu ve Güneydoğu Anadolu bölgelerindeki BİLSEM'lerde yöneticilik yapmaktadır. Ağa eklenen diğer 38 aktörün \%32's, Marmara, \%24'ü Karadeniz, \%13'ü Akdeniz, \%11'i Güneydoğu Anadolu, \%8'i İç Anadolu bölgesi ve \%3'ü Doğu Anadolu bölgesindeki BİLSEM'lerde yöneticidir. Sonuç itibariyle coğrafi olarak tüm bölgelerden katılım sağlanmıștır. Türkiye genelinde 2018 yılı itibariyle 131 aktif BILLSEM'den 68'i profesyonel destek ağında temsil edilmiștir. Türkiye'deki BİLSEM'lerin $\%$ 52'si ağda temsil edilmiştir.

\section{Verilerin Toplanması ve Analizi}

Araştırmanın verileri 2018 yılında, yarı-yapılandırılmış görüşme formu ile çevrimiçi olarak toplanmıştır. Verilerin toplanması sürecinde kullanılan listeleme, doldurma ve arşiv yaklaşımlarından (Marsden, 2005) biri olan doldurma yaklaşımı kullanılmıştır. Bu yaklaşımda katılımcılara hangi tür ilişki hakkında veri toplanıyorsa, bu ilişkide olan kişilerin isimlerini yazmaları istenir. Veri toplama süreci yaklaşık bir ay sürmüș, ikinci hatırlatmalardan sonra geriye dönüș olmayınca veri toplama sürecine son verilmiștir.

Araştırmada nitel verilerin analizinde betimsel ve içerik analizinden yararlanılmıștır. Nitel boyutta analizlerde kategorilerin oluşturulmasında araștırma sorularından yararlanılmıștır. Araștırmanın sosyal ağ analizi verilerinin analizinde ise kendine özgü analiz yaklaşımları olan yoğunluk, kümeleme katsayısı, derece, yakınlık, arasındalık, öz-vektör değerleri UCINET 6.0 (Borgatti, Everett ve Freeman, 2002) ile analiz edilmiş, klikler belirlenmiş ve Netdraw yazılımı ile grafikle (Borgatti, 2002) görsel olarak ortaya konmuştur.

\section{Geçerlik ve Güvenirlik}

A ̆g yaklaşımı ile yapılan araştırmalar, karmașıklık bilimlerindeki doğrusal olmayan dinamik yaklaşımları temel alır; aktörlerin özelliklerinden çok aktörler arası ilișkilerin oluşturduğu yapıya odaklandığı için gözlemler birbirinden bağımsız değildir. Bir aktör seçildiğinde aktörle ilişkili olan ve onun ağında yer alan tüm aktörler ağa dahil 
edilir ve ilişkiler örüntüsü bu biçimde oluşturulur. Bu nedenle bu veriler sosyometrik verilerdir (Eren, 2018a, 2018b). A ̆̆ analizi araştırmalarında geçerlik ve güvenirlik konusu, analiz birimi olarak seçilecek ilişki ve aktörlerin hassas biçimde seçilmesi ve tanımlanması ile sağlanır (Moolenear, 2012; Scott, 2000). Sosyal ağ araştırması, çoklu düzeylerde ve farklı içeriklerdeki ilișkileri analiz etmek üzere organize edilebilir. $\mathrm{Bu}$ nedenle ağ sınırlarının seçilmesi ve tanımlanması, sosyal ağ verilerinin toplanmasında, araștırmanın geçerlik ve güvenirliğinde önemli bir karardır (Carrington, Scott \& Wasserman, 2005; Uğurlu, 2013, 2016a, 2016b). Așağıda her bir analiz birimi bu araştırma açısından tanımlanmıştır:

Araştırmanın aktörleri. Bu araştırmanın aktörleri, 2018 yılında BİLSEM'lerde üst düzey yönetici (kurum müdürü) olarak çalışanlardan oluşmaktadır.

Araştırmada incelenen ilişki. Bu araştırmada taranan öncelikli ilişki aktörlerin profesyonel destek ağlarıdır. Profesyonel destek ağı, yöneticinin mesleki konularda erișebileceği tüm kiși ve kaynakları ve çeşitli biçimlerde etkileşim içinde olabileceği tüm süreçleri kapsar. Araştırmada BİLSEM profesyonel destek ağı, sadece diğer BİLSEM yöneticileri ile kendiliğinden gerçekleșen mesleki konulardaki yardımlaşma ilişkisi ile sınırlandırılmıştır. Bu tanım aynı zamanda personelin bağlamsal performans tanımlarına da karşllık gelmektedir.

Araştırmada sosyal ağ. Bu araştırmada sosyal ağ, MEB'na bağlı BİLSEM'lerde kurum müdürü olarak çalışan ve mesleki konularda üst kurumlar tarafından zorlanmaksızın birbirinden profesyonel destek alan yöneticiler ve bu profesyonel destek ilișkisinin oluşturduğu yapıdır. Araştırmanın verileri sosyal ağ analizine uygun tekniklerle analiz edilerek araștırmanın bulgularına ulașılmıștır.

\section{Bulgular}

Araştırmada BILLSEM yöneticilerinin profesyonel destek ağının analizinde 68 aktör (node=68) arasında 113 bağlantı (ties=113) bulunmuş ve ağ haritası oluşturulmuștur (Şekil 1).

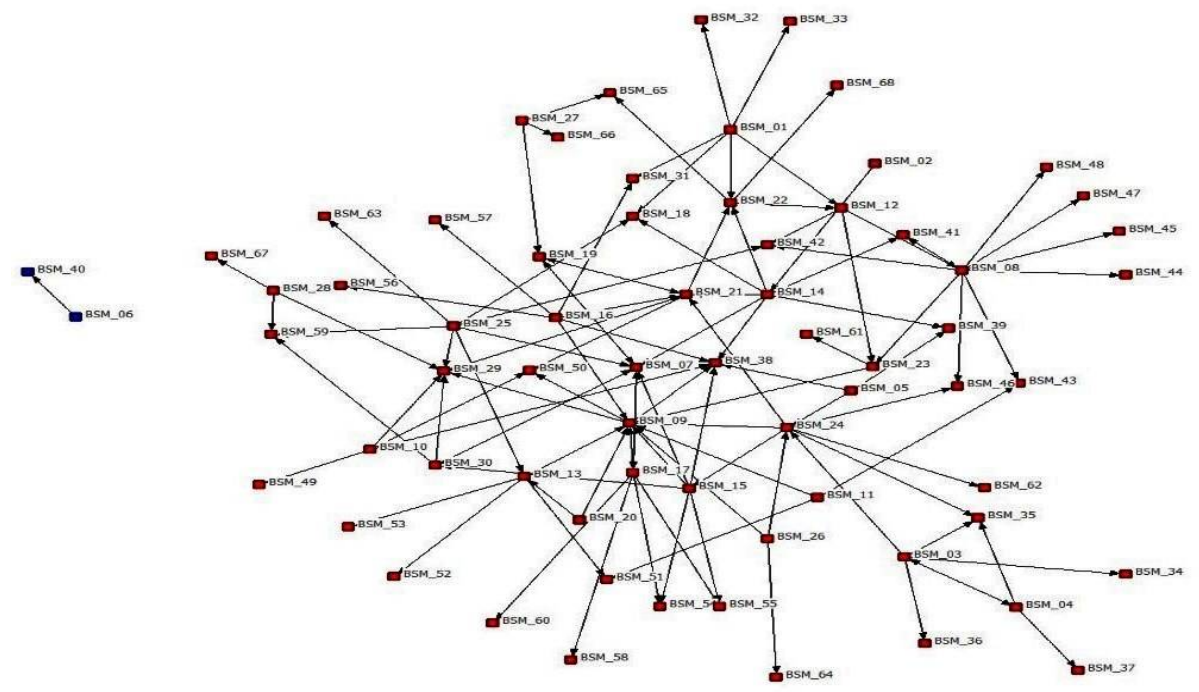

Şekil 1. BİLSEM yöneticilerinin profesyonel destek ağlarının genel görünümü (kırmızı aktörler= bağlantılı; mavi aktörler=bağlantısız) 
Ağ haritasında ilke olarak, ağ etkinliği yüksek aktörler ağın ortasında yer alırken, ağ etkinliği düşük aktörler kenarlarda yer almaktadır (Marsden, 2005; Scott, 2000). Araştırmada ağ haritasında BSM_9, BSM_7, BSM_38, BSM_21 olarak kodlanan aktörlerin ağın en merkezi yerinde konumlandığı bulunmuştur. Dolayısıyla bu aktörler BİLSEM yöneticileri arasındaki ağı en fazla yönlendiren, ağ olanaklarından en fazla yararlanan, diğer aktörlerle en fazla profesyonel destek ilişkisine giren kritik önemdeki aktörlerdir. Ağ haritasında kenarda iki aktör diğer aktörlerden ayrı ve sadece birbiri ile bağlantılı olarak bulunmuștur. Bu iki aktörün BİLSEM yöneticileri arasındaki profesyonel destek ağına katılmayarak sadece kendi aralarında destek verdiği anlaşılmaktadır. Bu aktörlerin neden diğerleri ile profesyonel destek iliş̧kisine girmedikleri araştırılabilir. Ağ haritasında her bir aktörün hangi aktörlerle ilişki içinde olduğu net biçimde ortaya konulmuştur.

\section{BİLSEM Yöneticilerinin Profesyonel Destek Aldıkları Konular}

Araştırmada elde edilen bulgulara göre, BILLSEM üst düzey yöneticileri diğer BİLSEM üst yöneticilerine sırasıyla mevzuat konusunda $(\mathrm{N}=24)$, yeni çalışmalarda işbirliği ve kolaylaştırıcılık konusunda fikir almak için $(\mathrm{N}=23)$, birlikte proje yapmak ya da projeler konusunda ortaklık aramak için $(\mathrm{N}=20)$, ortak organizasyonlarda yardım almak için ( $\mathrm{N}=13)$ ve öğrencilerle birlikte yapılan ziyaretlerde kolaylaştırıcılık için $(\mathrm{N}=8)$ danışmaktadırlar (Tablo 3).

\begin{tabular}{|l|c|c|}
\hline Danışılan Konular & $\boldsymbol{N}$ & $\%$ \\
\hline Mevzuat konusunda danışmak & 24 & 80 \\
\hline Yeni çalışmalarda işbirliği ve kolaylaştırıcılık konusunda fikir almak & 23 & 77 \\
\hline Proje (ortaklık, vb birlikte proje oluşturmak) & 20 & 67 \\
\hline Ortak organizasyonlar konusunda yardım almak & 13 & 43 \\
\hline Ziyaretler (öğrencilerle birlikte yapılan ziyaretlerde kolaylaştırıcılık) & 8 & 27 \\
\hline Sınav gibi uygulamalarda birliğin sağlanması & 3 & 10 \\
\hline Tanılama sürecinde işbirliği yapmak & 1 & 3 \\
\hline BİLSEM'e materyal ve demirbaş alımı & 1 & 3 \\
\hline
\end{tabular}

Tablo 3. BİLSEM Yöneticilerinin Birbirine Danıștıkları Konular

Araştırmada BİLSEM yöneticilerinin diğer BİLSEM yöneticilerine danıştıkları diğer konular, sınav ve diğer uygulamalarda birliktelik oluşturmak $(\mathrm{N}=3)$, tanılama sürecinde işbirliği yapmak $(\mathrm{N}=1)$ ve materyal ve demirbaş alımlarında fikir almak $(\mathrm{N}=1)$ olarak bulunmuştur.

\section{BİLSEM Yöneticilerinin Demografik Değişkenleri ve Destek Ağları}

Araştırmada eğitim düzeyi, kıdem, coğrafi bölgeye göre de ağ haritaları oluşturulmuştur. Eğitim düzeyleri dikkate alındığında katılımcı BİLSEM yöneticilerinin 4'ü doktora, 15'i yüksek lisans, 11'i lisans mezunu olarak belirlenmiștir (Şekil 2). 


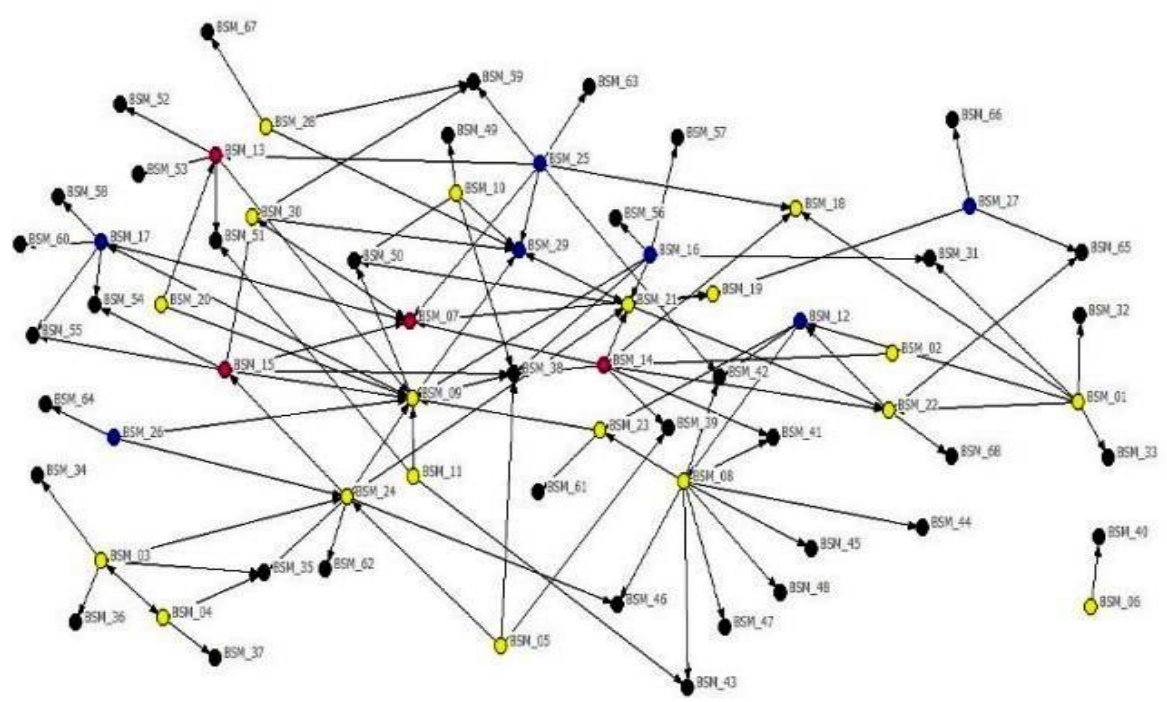

Şekil 2. BİLSEM yöneticilerinin profesyonel destek ağlarının eğitim düzeyi değişkenine göre görünümü (Doktora mezunu= pembe, yüksek lisans mezunu= sarı, lisans mezunu= mavi işaretli)

A ̆g haritası incelendiğinde farklı eğitim düzeylerinden aktörlerin ağın hem merkezi hem de çeperlerinde konumlandıkları bulunmuştur. Bununla birlikte, doktora mezunu olan BİLSEM yöneticileri (BSM_07, BSM_13, BSM_14, BSM_15) ağ içinde daha çok merkezi konumlarda yer almıştır. Ancak kıdem değișkenine göre oluşturulan ağ haritasinda BSM_07, BSM_08, BSM_09, BSM_13, BSM_17, BSM_18, BSM_25, BSM_29, BSM_30 aktörlerin ağ merkezinde konumlandığı bulunmuştur (Şekil 3).

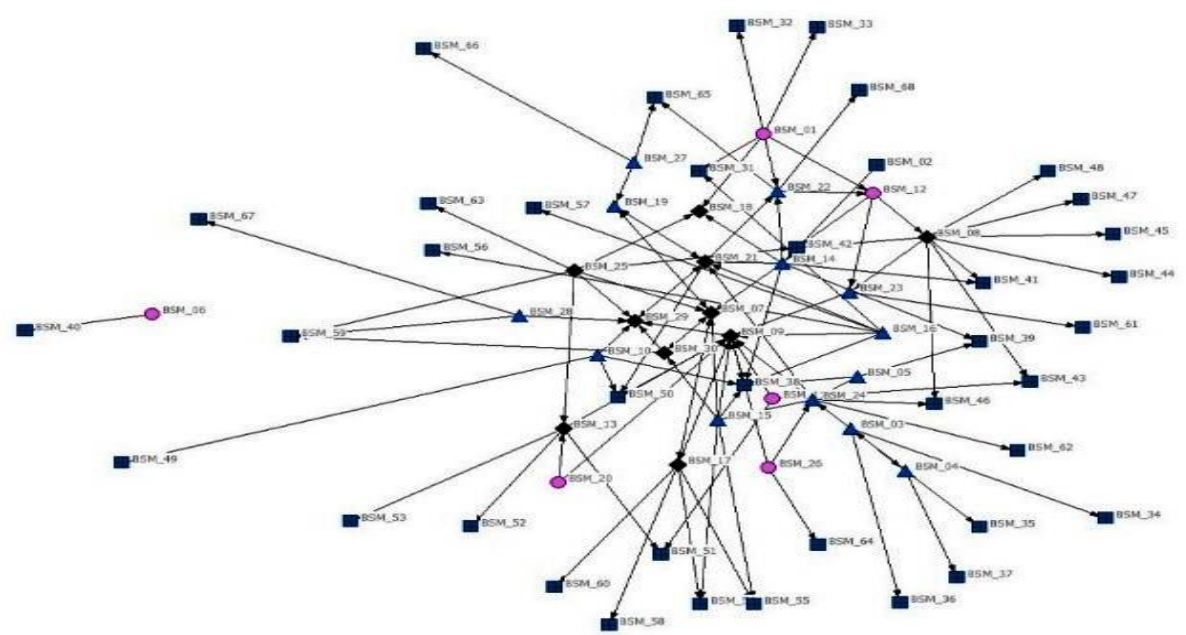

Şekil 3. BİLSEM yöneticilerinin profesyonel destek ağlarının kıdem değişkenine göre görünümü (1-5 yll= siyah, 5 yıl ve daha fazla= mavi üçgen, 1 yıl ve daha az=pembe işaretli; taralı kutular= eklenen aktörler olduğundan kıdemleri bilinmiyor) 
Araştırma bulgularında Şekil 3 ve Tablo 2 birlikte incelendiğinde, sayılan bu aktörlerin 5 yıl ve daha fazla süredir BİLSEM'lerde yönetici olduğu dikkate alınırsa, kıdemin profesyonel destek ilişkisinde eğitime kıyasla daha belirleyici olduğu söylenebilir. Araștırmada BİLSEM'lerin bulundukları bölgelere göre coğrafi olarak birbirine yakın illerdeki aktörlerin profesyonel olarak birbirini daha fazla desteklediği (kümelendiği) görülse de farklı bölgelerdeki aktörlerin destek ilişkisi kurmaları olumludur. Araştırmada farklı bölgelerde yer alan BILLSEM yöneticileri arasında mesleki danışma ilişkisi olduğu ve bölgeler arası farklılıklara rağmen anılan yöneticilerin birbirlerini destekledikleri bulunmuştur (Șekil 4).

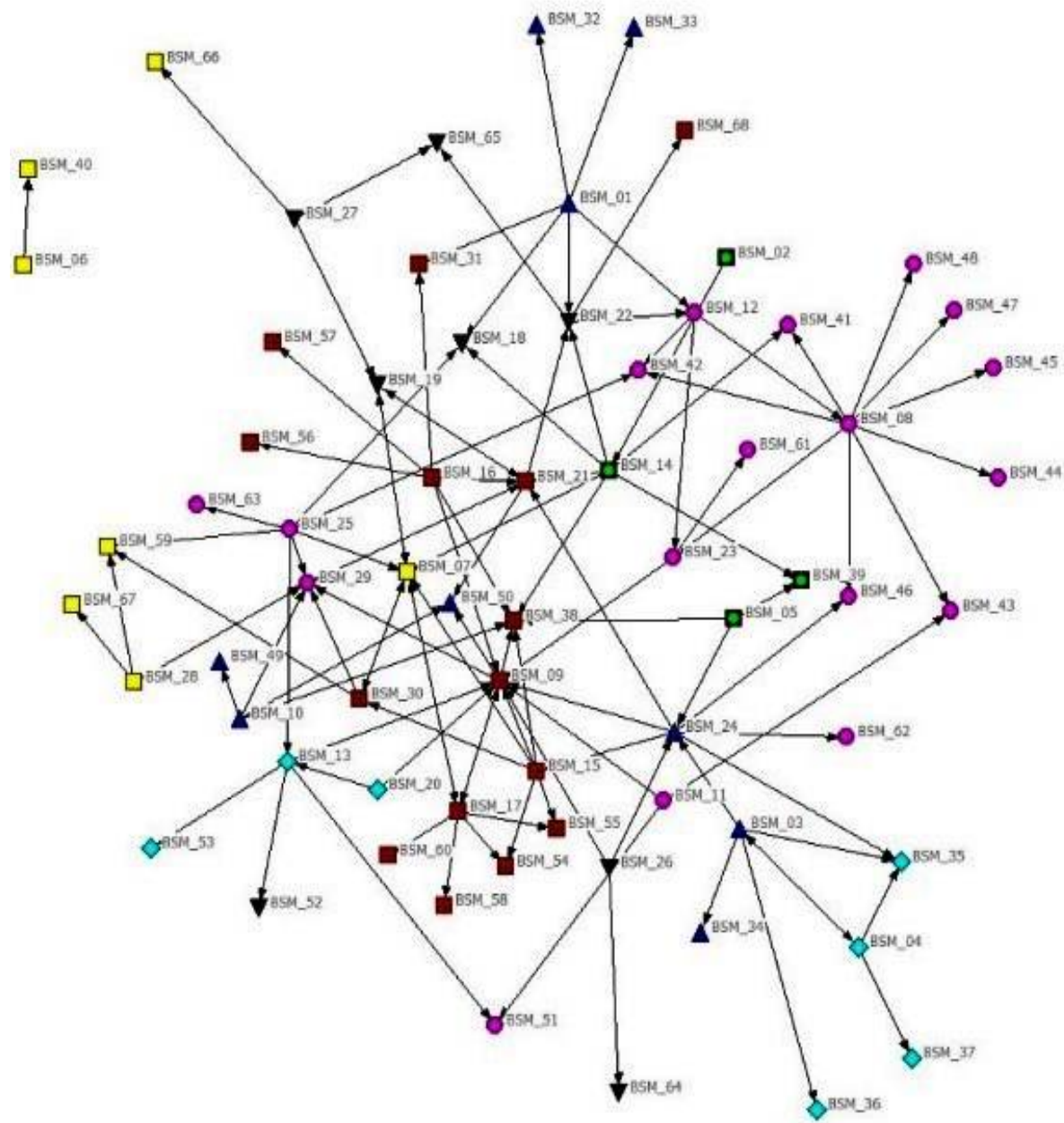

Şekil 4. BİLSEM yöneticilerinin profesyonel destek ağlarının coğrafi bölge değişkenine göre görünümü (kırmızı= Karadeniz Bölgesi; sarı= Ege Bölgesi; pembe= Marmara Bölgesi; koyu mavi= Akdeniz Bölgesi; açık mavi= Güneydoğu Anadolu B; siyah= İç Anadolu Bölgesi; yeșil= Doğu Anadolu Bölgesi) 


\section{BİLSEM Yöneticilerinin Profesyonel Destek Ă̆ Yapısal Özellikleri}

BİLSEM profesyonel destek ağının yapısal özellikleri açısından elde edilen bulgulara göre, 68 aktör arasında 113 bağlantı bulunmuștur. Tüm ağ büyüklügü 68 olarak gerçekleşmiştir (network size=68). Araştırmada elde edilen bulgulara göre, BİLSEM profesyonel destek ağının yoğunluğu \% 25 (D=0.025, Ss.= 0.156, Avg. Degree= 1.662) olarak bulunmuştur. Araştırmada BİLSEM profesyonel destek ağının kümelenme katsayısı 0.058 (Clustering Coefficient= 0.058) olarak bulunmuştur. Analizlerin özeti Tablo 4'te verilmiștir.

\begin{tabular}{|l|l|l|l|l|}
\hline $\begin{array}{l}\text { Ağ büyüklüğü } \\
\text { (Network Size) }\end{array}$ & $\begin{array}{l}\text { Bağlantı sayısı } \\
\text { (Ties) }\end{array}$ & $\begin{array}{l}\text { Yoğunluk } \\
\text { (Density) }\end{array}$ & Ss. & $\begin{array}{l}\text { Kümeleme } \\
\text { Katsayısı } \\
\text { (Cluster } \\
\text { Coefficient) }\end{array}$ \\
\hline 68 & 113 & 0.025 & 0.156 & 0.058 \\
\hline
\end{tabular}

Tablo 4. BİLSEM Yöneticilerinin Profesyonel Destek Ağlarının Ağ Yapısal Özellikleri

Araștırmada 30 yöneticinin profesyonel destek ağının büyüklüğü 68 yöneticiden oluşmuştur. Ağ yoğunluğuna göre kurulabilecek maksimum destek ilişkisinin \% 25'i kurulmuştur. Kümelenme katsayısının yüksek olması, iç bağlantıların daha fazla, dış bağlantıların az olması anlamına gelir (Scott, 2000). Araştırmada kümeleme katsayısı, ağın yoğunluğundan daha yüksek bulunmuștur. BİLSEM profesyonel destek ağı açısından olması gerektiği gibi kendi düzeylerindeki meslektaşları ile farklı illerde olmaları nedeniyle gevșek bağlantılı olmakla birlikte, daha sıkı bağlantılı oldukları dış bağlantılara da sahip olduklarını göstermektedir.

Araştırmada gerek yoğunluk gerekse kümeleme katsayılarının orta düzeyde ve düşük bulunması diyagramlarda gruplaşmalar ve klikler olduğunun göstergesidir. Sosyal ağ analizinde bunun ortaya konulabilmesi için klik analizleri yapılmaktadır. Klikler belirgin bir takım ortak özelliklere göre oluşur ve örgütsel işlevsellik (bilgi toplama ve yayma gibi örgütsel düzeydeki konular gibi) önem taşır (Krackhardt, 1998). Araştırmada yapılan klik analizinde BİLSEM yönetici profesyonel destek ağında 12 klik bulunmuştur. Kliklerde yer alan aktörlerin listeleri Şekil 5'te verilmiștir. 

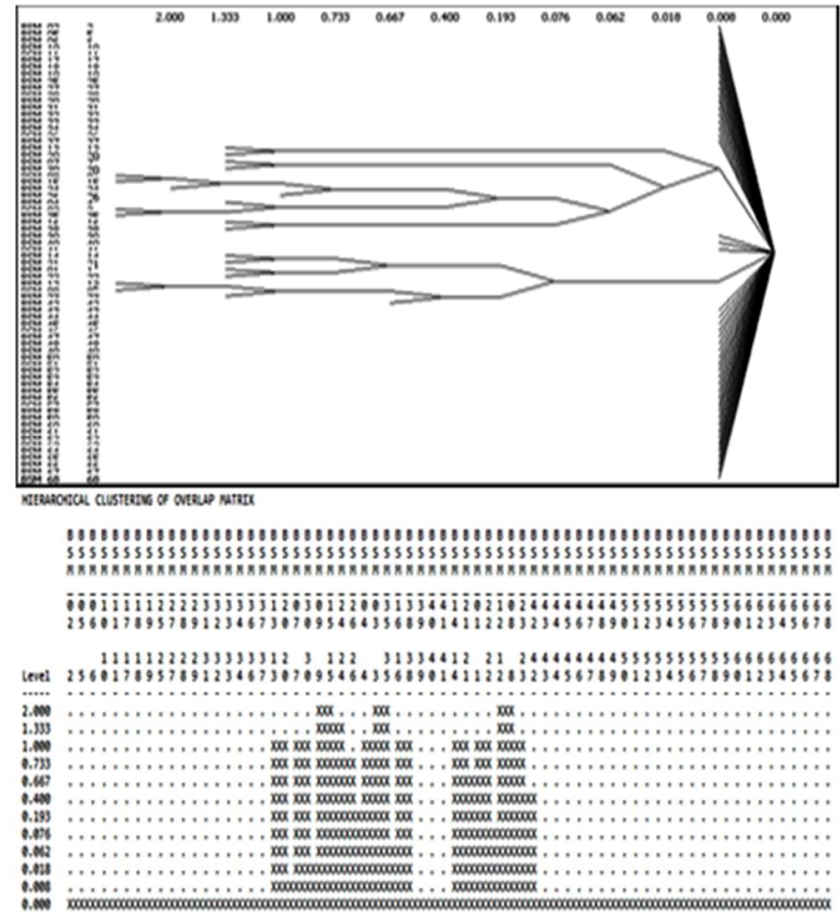

\section{Minimum Set size: \\ Input dataset:}

\section{2 cliques found.}

1: BSM_09 BSM_15 BSM_24 2: BSM_09 BSM_15 BSM_38 3: BSM 09 BSM 13 BSM 20 4: BSM_09 BSM_16 BSM_38 5: BSM_09 BSM_24 BSM_26 5: BSM_09 BSM_24 BSM_26 6: BSM_03 BSM_24 BSM_35 8: BSM_07 BSM_15 BSM 30 9: BSM_08 BSM_12 BSM_23 10: BSM_08 BSM_12 BSM_42 11: BSM_01 BSM_12 BSM_22 12: BSM_14 BSM_21 BSM_22

Şekil 5. BİLSEM yöneticilerinin profesyonel destek ağlarının klik diyagram ve listeleri

Şekil 5’te görüldüğü gibi, araştırmada, BİLSEM yönetici profesyonel destek ağ yapısı içinde yöneticilerin hangi diğer yöneticilerle destek ilişkisi içinde olduğu ve grupların kaçar kişilik olduğu ayrıntılı bir biçimde ortaya konulmuştur.

\section{BÍLSEM Yöneticilerinin Profesyonel Destek Ağı Bağ Gücü}

Sosyal ağlarda bağ gücü, ağ içindeki aktörlerin tek tek özelliklerini ve bu aktörlerin ağ içindeki konumlarını ortaya koyan, ağ içinde etki kapasitesi yüksek aktörleri belirlemeyi sağlayan analiz yaklaşımıdır (Ö̈ztaş \& Acar, 2004). Araştırmada BİLSEM yöneticilerinin profesyonel destek ağlarının konumlarını ortaya koyan merkezîlik ölçümleri derece, yakınlık, arasındalık ve özvektör merkezilliği analizleri (Scott, 2000) yapılarak öne çıkan aktörlere ilişkin bulgular Tablo 5'te verilmiştir.

\begin{tabular}{|c|c|c|c|c|}
\hline $\begin{array}{c}\text { Aktör } \\
\text { (ID) }\end{array}$ & $\begin{array}{c}\text { Derece } \\
\text { (Degree) }\end{array}$ & $\begin{array}{c}\text { Arasındalık } \\
\text { (Betweenness) }\end{array}$ & $\begin{array}{c}\text { Yakınlık } \\
\text { (Closeness) }\end{array}$ & $\begin{array}{c}\text { Özvektör } \\
\text { (Eigenvector) }\end{array}$ \\
\hline BSM_01 & 6.000 & 158,188 & 349.000 & 0,076 \\
\hline BSM_07 & 6.000 & 160,72 & 319.000 & 0,203 \\
\hline BSM_08 & 10.000 & 329,216 & 328.000 & 0,104 \\
\hline
\end{tabular}




\begin{tabular}{|c|c|c|c|c|}
\hline $\begin{array}{c}\text { Aktör } \\
\text { (ID) }\end{array}$ & $\begin{array}{c}\text { Derece } \\
\text { (Degree) }\end{array}$ & $\begin{array}{c}\text { Arasındalık } \\
\text { (Betweenness) }\end{array}$ & $\begin{array}{c}\text { Yakınlk } \\
\text { (Closeness) }\end{array}$ & $\begin{array}{c}\text { Özvektör } \\
\text { (Eigenvector) }\end{array}$ \\
\hline BSM_09 & 12.000 & 640,361 & 288.000 & 0,423 \\
\hline BSM_13 & 6.000 & 185,885 & 328.000 & 0,153 \\
\hline BSM_14 & 8.000 & 243,053 & 310.000 & 0,209 \\
\hline BSM_15 & 7.000 & 146,79 & 311.000 & 0,287 \\
\hline BSM_16 & 6.000 & 186,707 & 317.000 & 0,204 \\
\hline BSM_17 & 6.000 & 168,426 & 323.000 & 0,165 \\
\hline BSM_21 & 7.000 & 324,735 & 303.000 & 0,249 \\
\hline BSM_22 & 6.000 & 226,69 & 324.000 & 0,131 \\
\hline BSM_24 & 9.000 & 530,398 & 297.000 & 0,289 \\
\hline BSM_25 & 7.000 & 238,766 & 321.000 & 0,16 \\
\hline BSM_29 & 6.000 & 206,496 & 310.000 & 0,223 \\
\hline BSM_38 & 6.000 & 122,317 & 313.000 & 0,262 \\
\hline BSM_50 & 3.000 & 31,091 & 326.000 & 0,153 \\
\hline
\end{tabular}

Tablo 5. BİLSEM Yönetici Profesyonel Destek Ağına İlişkin Merkezileșme Ölçümleri

Araştırma bulgularına göre, profesyonel destek ağının en merkezi (derece merkeziliği en yüksek) aktörü BSM_09 (deg=12) olarak belirlenmiştir. Profesyonel destek ağının derecesi en yüksek, başka bir ifade ile ağ içinde en merkezi konumda yer alarak diğerleri ile en fazla profesyonel destek ilișkisine giren yöneticileri BSM_09'un yanı sıra sırasıyla BSM_24 (deg=9) ve BSM_14 (deg=8) kodlu aktörlerdir.

Yakınlık merkeziliği (closeness centrality), ağdaki bir aktörün diğer aktörlere, doğrudan veya dolaylı olarak yakınlığı veya uzaklığının derecesidir. Aktörün ağ içinde bilgiye erişim yeteneğini, ağdaki diğer aktörlere ne kadar hızlı bağlanabileceğini yansıtır (Scott, 2000). Araștırmada elde edilen bulgulara göre BSM_01 (Clo= 349.000) BILSEM yönetici profesyonel destek ağında bilgiye erișim yeteneği en yüksek aktör olarak bulunmuştur. Yakınlık merkezîliği yüksek aktörler, hem kendi bağlantıları hem de arkadaşlarının bağlantılarını kullanarak ağ içinde diğer tüm aktörlere en yüksek düzeyde ulaşabilir. Bu nedenle bilgiye erişimi firsatları da daha fazladır (Kilduff \& Tsai, 2007).

Arasındalık merkeziliği (betweeness centrality), sosyal sermaye teorisinde ileri sürülen yapısal boşluk kuramına bağlı olarak aktörler arası ilişkilerin olmadığı durumlardan oluşan yapısal boşluklarda konumlanan ve köprü görevi üstlenen aktörlerin daha fazla fayda sağlayabileceği teorik temeline dayanmaktadır (Burt, 1992). BİLSEM yönetici destek ağında diğer aktörler arasındaki bağlantısızlıkları kendi lehine çevirerek köprü işlevi gören ve bu bağlantısız aktörler arasında bağlantı kurulmasında kritik rol oynayan en yüksek aktör BSM_09 (Betw.=640,361) olarak bulunmuştur. BSM_24, (Betw.=530,398), BSM_08 (Betw.=329,216), ve BSM_21 (Betw.=324,735) kodlu aktörler aynı ağda köprü işlevi görmektedirler.

Araştırmada BİLSEM yönetici profesyonel destek ağının özdeğeri en yüksek aktörü BSM_09 (Eigenvector=0,423) olarak bulunmuștur. Özdeğeri en yüksek diğer aktörler, BSM_24 (Eigenvector=0,289), BSM_15 (Eigenvector= 0,287), BSM_38 (Eigenvector=0,262) ve BSM_21 (Eigenvector=0,249) olarak bulunmuştur. Bu ölçüm bütün bağlantıların eşit değerlerde olmadığını ve kişinin merkezi bir konumda olabilmesi 
için bağlantıların sayısı kadar bağlantıların kalitesinin de önemli olduğunu varsayar. Yani bir aktörün az sayıda yüksek kaliteli bağlantıya sahip olması çok sayıda orta kalitede bağlantıya sahip olmasından daha önemlidir (Marsden, 2005; Öztaş \& Acar, 2004). Böylece araştırmada BİLSEM yöneticilerinin profesyonel destek ağındaki konumları nedeniyle ağın içinde etkin rol üstlenen tüm aktörler verilere dayalı olarak ortaya konulmuştur.

\section{Tartışma}

Sosyal ağ yaklaşımı geleneksel örgüt teorilerinin aksine çalışanların başarılarını sadece bireysel yeterliklerinin değil, örgütün ilișkiler ağındaki konumlarının belirlediğini ileri sürmektedirler (Borgatti \& Ofem, 2010). Modern örgütlerin etkililiği, sadece çalıșanların birtakım teknik bilgi ve becerilere sahip olmaları ile değil bu beșeri sermayenin örgütte paylașılmasıyla sağlanabilir. Dolayısıyla örgütlerde verimliliğin sağlanabilmesi, sadece nitelikli çalışanların örgütte istihdam edilmesi ile değil bu beșeri sermayenin etkileşimi ile oluşan sosyal sermayenin de geliştirilmesini ve iyi yönetilmesini gerektirmektedir.

Bağlamsal performansın en belirgin özelliği, kendini işe adama ve diğerlerinin işini kolaylaştırma olarak sayılabilir (Reilly \&Aronson, 2012). Bu bakış açısı ile örgütteki çalıșanlar arası ilișkiler ve destekleyici davranışlar bağlamsal davranıșın en belirgin özelliklerinden biri olarak düşünülebilir (Finkelstein \& Penner, 2004; Goodman \& Svyantek, 1999; Somech \& Drach-Zahavy, 2004; Wagner \& Rush, 2000, Akt: Reilly \& Aronson, 2012). Bu noktadan hareketle bu araştırmada BİLSEM üst düzey yöneticilerinin bağlamsal performansının bir boyutu olan diğerlerinin ișini kolaylaştırma davranışı, üst yöneticilerin arasındaki profesyonel destek ağı örüntüsü açığa çıkarılarak analiz edilmiş, ağı oluşturan aktörler arası ilişkiler hem ağ yapısal özellikleri hem de aktörler arası ilişkilerin karakteristik özellikleri açısından ortaya konmuştur.

Araştırmada Türkiye'nin farklı il ve bölgelerinde yer alan ve coğrafi mesafe olarak birbirinden oldukça uzakta olan BİLSEM yöneticilerinin aralarındaki destek ilişkilerinin analizinde, görev tanımlarında olmamasına rağmen birbirlerini destekledikleri, görüş aldıkları, yardımlaştıkları, birbirlerinin işlerini kolaylaştırdıkları bulunmuştur. Bu bulgu, çeşitli araştırmalarla da uyumludur (Brass. 1995; Feroli, 2015; Moolenaar, Sleegers \& Daly, 2012; Penuel, Sun, Frank \& Gallagher, 2012; Spillane, Kim \& Frank, 2012). Örgütlerde etkili ve verimli çalışmayı sağlayan koşullar çalışanların görev tanımlarında olmasa da yaptıkları bazı davranışlarında ortaya çıkmaktadır. Verilen görevi tanımlandığı biçimde yapmak önemli olmakla birlikte, örgütün zor zamanlarında ve koşullarında sadakatle örgüte destek sunmak, işine zamanında gelip gitmek, dıșarıda örgütünü iyi temsil etmek, çalışma arkadaşlarına destek olmak ve onların işlerini kolaylaştırmak gibi davranışlar, örgütün verimliliği üzerinde en az görev davranışları kadar etki yaratmaktadır. Bahsedilen ve örneklenen tüm bu davranışlar ise bağlamsal performansın içeriğini oluşturmaktadır. Bağlamsal performans, çalıșma ortamının örgütsel, sosyal ve psikolojik havasını zenginleştiren davranışları kapsamaktadır (Borman \& Modowidlo, 1993). Araştırma bulguları, yöneticilerin birbirini genel olarak desteklemekle birlikte ağda bazı aktörlerin daha fazla öne çıktığını göstermiștir.

Araştırmada demografik değişkenler açısından yapılan analizlerde yöneticilerin destek ilişkisinde kıdem değişkenine eğitim değişkeninden daha çok önem verildiği bulunmuştur. BSM_07, BSM_13, BSM_14 ve BSM_15, doktora mezunu olan yöneticiler olarak lisans mezunlarına göre daha çok danışılmalarına karşın BSM_07, BSM_08, BSM_09, BSM_13, BSM_17, BSM_18, BSM_25, BSM_29 ve BSM_30 yöneticilik kidemi daha fazla olan aktörler olarak ağın merkezinde yer almışlardır. BSM_07 ve BSM_13 hem kıdemi yüksek hem de doktora düzeyinde eğitim almıştır. Bununla birlikte ağ içinde en 
fazla destek ilişkisine giren yönetici BSM_09 olarak bulunmuştur. Benzer biçimde BSM_24, BSM_14 profesyonel destek ağında öne çıkan aktörlerdir.

Araştırma elde edilen sonuçlar eğitim düzeyi ve kıdemin de ötesinde araştırılması gereken farklı etkenlere işaret etmektedir. Çünkü her iki değişkene göre ağın merkezinde kümelenme artmakta birlikte ağın en etkin aktörleri ne eğitim düzeyi ne de kıdemi en yüksek olan gruptan değildir. Bağlamsal performans üzerine yapılan çalışmalarda en fazla çalışanların kişilik özellikleri üzerinde durulmuştur. Motowidlo, Borman ve Schmitt (1997) kişilik özellikleri değişkeninin bilişsel yeteneklere nazaran bağlamsal performansın daha doğru yordayıcısı olacağını ileri sürmüștür. Hurtz ve Donovan (2000) tarafından yapılan bir meta-analizde, duyarlılık, uyumluluk ve duygusal istikrarın bağlamsal performansı öngördüğünü göstermiştir. Bell (2007), vicdanlılık ve uyumluluk ile takım performansı arasında güçlü bir ilișki bulmuștur. Hofstede (1984) tarafından yapılan çalıșmalarda, kültür ile bağlamsal performans ilişkisi güç mesafesi ve bireyciliktoplulukçuluk değişkenleri üzerinden kurulmuştur. Güç mesafesi, liderlerin astları üzerinde sahip olduğu etki olarak değerlendirilen kültürel bir özelliktir. Güç mesafesi yüksek kültürlerde liderin astları üzerindeki etkisi asimetriktir ve olduğundan daha fazla hissedilmektedir. Güç mesafesi düştüğünde etki simetrik hale gelmektedir. Başka bir ifade ile lider ve izleyenler birbirini etkilemektedir. Pain ve Organ (2000), güç mesafesi düşük ve yüksek toplumların lider davranışlarının ve yönetim yaklaşımlarının birbirinden farklı olması gerektiğini belirtmiştir. Toplulukçu kültürlerde nezaket, hoşgörü, yardımseverlik, işe adanma, birbirinin işini kolaylaştırma gibi davranışlar işin bir parçası olarak görülürken bireyci kültürlerde kişinin kendi kişisel değerlerine ve çıkarlarına bağlıdır (Hofstede, 1984; Paine \& Organ, 2000).

Ancak bu özelliklerin yanıltıcı olabileceğine ilişkin görüşler de mevcuttur. Reagans, Zuckerman ve McEvily (2004) proje takımları üzerine yapılan araştırmada, etkili takımlar kurmak ve çalıştırmak için ekip üyelerinin demografik özelliklerine odaklanmanın problemli olduğunu, yöneticinin uygun teknikler kullanma konusunda kısıtlandığını ya da yapabileceklerinin sınırlı olduğunu, nitelik olarak homojen gruplar olsa bile takım üyelerinin yaș, cinsiyet, eğitim gibi demografik özellikleri yerine sosyal ağ içindeki konumlarının dikkate alınarak ekibin sosyal sermayesinin yönetilmesinin performans üzerinde etkisinin daha yüksek olduğunu bulmuştur. Akaka ve Chandler (2011) sosyal rollerin değer ağlarında değişim için nasıl bir kaynak olarak kullanılabileceğini araștırmış ve çalışanların birlikte yaratma ve ortak üretim anlayışının oluşturulmasında çalışanların sürekli olarak farklı aktörlerle değer yaratma çabalarında kaynak olarak sosyal rolleri ve sosyal konumlarını kullandıklarını ortaya koymuştur. Başka bir ifade ile kişiler, demografik özelliklerinden ve niteliklerinden daha çok ağ içindeki sosyal konumlarını ve sosyal rollerini kaynak olarak kullanmaktadır.

Sonuç olarak sosyal ağ yaklaşımıyla yapılabilecek analizlerin bağlamsal performansın ölçümünde yukarıdaki yaklaşımların tamamlayıcısı olarak kullanılması, hem sosyal yapının ve ilişkilerin derinlemesine incelenmesini ve yapısal faktörleri belirlemeyi hem de kişilik özellikleri, kültür, liderlik gibi etken faktörlerin birlikte ele alınarak daha bütüncül bir değerlendirme ortaya koymayı sağlayacaktır. Araştırma bulgularına göre bazı yöneticiler, diğer yöneticilerin desteklenmesinin kendilerine bir görev olarak verilmemesine rağmen birbirine yine de daha fazla yardım etmekte, birbirine mesleki konularda danışmakta ve mesleki gelişimlerini destekleyerek ișlerini kolaylaștırmaktadırlar. Araștırma bulguları bunu açık biçimde verilere dayalı olarak göstermektedir. Bu açıdan bakıldığında sosyal ağ yaklaşımının bağlamsal performans davranışlarını değerlendirmede kullanılabilirliği açıktır.

Araştırmanın bir diğer önemli bulgusu Türkiye'nin farklı il ve bölgelerinde yer alan ve mesafe olarak birbirinden oldukça uzakta olan BILSEM yöneticilerinin aralarındaki destek ilişkilerinin mesafeye ve bölgelere göre dağılımıdır. Sosyal ağ 
araştırmalarında coğrafi konum, uzaklık ya da mesafe açısından önem taşımaktadır ve analizlere dâhil edilme nedenlerinden biri, yakın olan aktörlerin birbiri ile etkileșime ve dolayısıyla diğer ağ ilişkilerinin kurulmasını kolaylaștıracak ortam oluşturmaya daha elverişli koşullara sahip olmasıdır (Kilduff \& Tsai, 2007). Araştırma bulgularına göre, yönetici profesyonel destek ağına tüm bölgelerden katılım olmuştur. Beklendiği gibi, coğrafi olarak birbirine yakın illerdeki aktörlerin profesyonel olarak birbirini daha fazla desteklediği bulunsa da farklı bölgelerdeki aktörlerin aralarında hiyerarşik bir bağ olmamasına rağmen destek ilişkisi kurmaları olumludur. Son zamanlarda gündemde yer alan kutuplaşma söylemlerine karşın bu araștırmada bölgesel olarak bir kutuplaşma ya da dişlama bulgusuna rastlanmamıștır.

\section{Sonuç ve Öneriler}

$\mathrm{Bu}$ araştırmada elde edilen bulgular, bağlamsal performansın ölçümünde sosyal ağ analizinin kullanımının yeni bir açılım getireceğini göstermektedir. Örgüt ve yönetim bilimi alanındaki son yıllardaki gelişmeler, 21. Yüzyılda yaşanan yoğun değișimin pek çok konuda olduğu gibi örgütlerdeki çalışma ilişkilerini de dönüştürdüğünü ortaya koymuştur. 21. yüzyıldaki yeni çalışma ilişkilerinde çalışanların özellikleri ve onlardan beklentiler kadar çalışanların da örgütten ve çalışma ortamından beklentileri değişime uğramıştır (De Langhe, Puntoni \& Larrick, 2017, s. 87-88). Bu süreçte, sanayi çağına özgü psikolojik sözleşmenin (Çankır \& Yener, 2017, s. 11) bu yeni karmaşık, hızlı değișen, çok odaklı, dinamik bilgi ve iletişim çağının örgütsel ilişkilerini açılamakta yetersiz kalacağı açıktır. Sosyal ağ analizi, ortaya koyduğu analiz yaklaşımlarıyla bu konudaki boşluğu doldurmaktadır.

Araştırma bulgularına göre şu önerilerde bulunulabilir:

Performans değerlendirmede görev performansı yanı sıra bağlamsal performansın da değerlendirilmesinde diğer meslektaşlarına destek sunan aktörlerin ödüllendirilme sistemleri oluşturulabilir. Diğer meslektaşlarına katkı sunan yöneticilerin ödüllendirilmesi, ağ içinde daha etkin ve verimli çalışmaya katkı sunan aktörlerin sayıca artmasına yardımcı olacaktır.

Sosyal ağ analizi, gerek insan kaynakları uygulamaları gerekse bu uygulamaların içinde yer alan performans değerlendirmede geleneksel yaklaşımların tamamlayıcısı olarak yeni bir bakış açısı getirebilir. Ancak bu konuda Türkiye'de yapılan çalışma sayısı oldukça kısıtlıdır. Bu yaklaşımla yapılan araştırmalar yaygınlaştırılabilir. Yapılan çalışma sayısı arttıkça ağ karşılaştırmaları yapma olanakları da artacaktır.

$\mathrm{Bu}$ araștırma, tüm BİLSEM'lerin katılımı sağlanarak yapılabilir ve her iki ağ karşılaştırılabilir ya da boylamsal araștırmalar yoluyla ağdaki değişim izlenebilir. Bu sayede BİLSEM'lerin geliştirilmesi için gerekli kararlar verilere dayalı olarak alınabilir.

\section{KAYNAKÇA}

ABRAHAM, G. C. (1982). Gifted education: the recruitment/selection process of teachers for gifted elementary programs and the perceptions of teachers and principals. (Unpublished Doctoral Thesis). University of Southern, California.

AKAKA, M.A. \& CHANDLER, J.D. (2011). Roles as resources: A social roles perspective of change in value networks. Marketing Theory, 11 (3), 243-260. https://doi.org/10.1177/1470593111408172 
Zeynep Eren, "Bilim Sanat Merkezi Yöneticilerinin Bağlamsal Performansının Sosyal Ağ Analizi Yaklaşımı ile Değerlendirilmesi”, İstanbul Gelişim Üniversitesi Sosyal Bilimler Dergisi, 7 (1), Nisan 2020, ss. 50-73.

ALTUN, T. \& VURAL, S. (2012). Bilim ve sanat merkezinde (BİLSEM) görev yapan öğretmen ve yöneticilerin mesleki gelişim ve okul gelişimine yönelik görüşlerinin değerlendirilmesi. Elektronik Sosyal Bilimler Dergisi. Cilt 11 (42), 152-177.

ASLAN, M. \& YILDIRIM, A. (2017). Hastanede çalışan hemșirelerde bağlamsal performans ölçeğinin geçerlik ve güvenirliği. Hemşirelikte Eğitim ve Araştırma Dergisi, Cilt 14 (2), 104-111.

AYDIN, İ. (2005). Öğretimde denetim: Durum saptama, değerlendirme ve geliştirme. Ankara: Pegem.

BAŞAK, S. \& ÖZTAȘ, N. (2010). Güven ağbağları, sosyal sermaye ve toplumsal cinsiyet. Gazi Üniversitesi İktisadi ve İdari Bilimler Fakültesi Dergisi, 12 (1), 27-56.

BALKUNDI P, \& HARRISON D.A. (2006). Ties, leaders and time in teams: Strong inference about network structure's effects on team viability and performance. Academy of Management Journal, 49 (1), 49-68.

BELL, S.T. (2007). Deep level composition variables as predictors of team performance: A meta-analysis. Journal of Applied Psychology, 92, 595-615.

BORGATTI, S.P. (2002). Netdraw network visualization, Harvard, MA: Analytic Technologies.

BORGATTI, S.P., EVERETT, M.G., FREEMAN, L. (2002). UCINET for windows, version 6.59: Software for social network analysis. Harvard, MA: Analytic Technologies.

BORGATTI, S. P.,, OFEM, B. (2010). Overview: Social network theory and analysis. Social network theory and educational change (pp. 17-30). Cambridge: Harvard Education.

BORMAN, W. C., MOTOWIDLO, S.J. (1993). Expanding the criterion domain to include elements of contextual performance. Personnel selections in organizations (ss.7183) San Francisco: Jossey-Bass.

BRASS, D. J. (1995). A social network perspective on human resources management. Research in Personnel and Human Resources Management, 13, 39-79.

BURT, R.S. (1992). Structural holes: The social structure of competition. Cambridge, MA: Harvard University Press.

COLEMAN V.I, \& BORMAN W.C. (2000). Investigating the underlying structure of the citizenship performance domain. Human Resource Management Review, 10, 25-44.

CUMMINGS J.N. \& CROSS, R. (2003). Structural properties of work groups and their consequences for performance. Social Networks, 25 (3), 197-210.

ÇANKIR, B.,YENER, S. (2017). Ișs'te pozitif davranış. Konya: Çizgi Yayınevi.

De LANGHE, B., PUNTONI, S. \& LARRICK, R. (2017 Eylül). Lineer olmayan dünyada lineer düşünmek. Harvard Business Rewiev Türkiye. 82-92.

EREN, Z. (2018). Biçimsel ve biçimsel olmayan örgüt yapılarının sosyal ağ analizi: Öneri ve güven ağları örneği. Hacettepe Üniversitesi Eğitim Fakültesi Dergisi. Advance online publication. doi:10.16986/HUJE.2018041879

EREN, Z. (2018b). Bağlantıcılık teorisi ve öğretmen adaylarının öğrenme ağlarının sosyal ağ analizi. Turkish Studies Educational Sciences, Cilt 13(19), 717-753.

FEROLI, S. P. (2015). Social networks and novice teachers: An examination of supports provided through social networks. (Doctoral Dissertation). Oklahoma State University, Stillwater.

FREEMAN, L. C. (2004). The development of social network analysis: A Study in the sociology of science. Vancouver: Empirical Press.

DAFT, R.L. (1997). Management. Forth Worth: The Dryden Press.

GREENSLADE JH. \& JIMMIESON NL. (2007). Distinguishing between task and contextual performance for nurses. Development of a job performance scale. Journal of Advanced Nursing, 58 (6), 602-11. 
Zeynep Eren, "Bilim Sanat Merkezi Yöneticilerinin Bağlamsal Performansının Sosyal Ağ Analizi Yaklaşımı ile Değerlendirilmesi”, İstanbul Gelişim Üniversitesi Sosyal Bilimler Dergisi, 7 (1), Nisan 2020, ss. 50-73.

HOFSTEDE, G. (1984). Culture's consequences: International differences in workrelated values, London: Sage,

HUNTER, D. S. (2015). Combining theoretical perspectives on the organizational structure performance relationship. Journal of Organization Design, 4 (2), 24-37.

HURTZ, G.M., \& DONOVAN, J.J. (2000). Personality and job performance: The big five revisited. Journal of Applied Psychology, 85, 869-879.

JAWAHAR I, \& FERRIS GR. (2011). A longitudinal investigation of task and contextual performance influences on promotability judgements. Human Performance. 24, 251-269.

KAHRAMAN, Ç.A., SÖZEN, H.C. \& MEYDAN, C.H. (2018). Bireylerin ağ düzeneğindeki yerinin oluşmasında lider-üye etkileşiminin rolü: Sosyal ağ analizi yaklașımı. LAÜ Sosyal Bilimler Dergisi, IX (I), 12-34.

http://dergipark.gov.tr/download/article-file/503753

KAPUSUZOĞLU, S., UĞURLU, Z. (2015). Cost in cooperatıve leadership: The network approach as an organising strategy for the excessive flow of information in institutions. 1st. International Conference On Lifelong Learning and Leadership For All, 29-31 October 2015, (ss. 99), Olomouch: Palacky University \& Morovian University College Olomouch.

KAYA, N. G. (2013). Üstün yetenekli öğrencilerin eğitimi ve BİLSEM’ler. Erzincan Üniversitesi Eğitim Fakültesi Dergisi, Cilt 15 (1), 115-122.

KAZU, Y.,\& ŞENOL,C. (2012). Üstün yetenekliler eğitim programlarına ilişkin öğretmen görüşleri (Bilsem Örneği). E-International Journal of Educational Research. Cilt 3 (2), 13-35.

KILIÇ, C. V. (2015). Türkiye'de üstün ve üstün yetenekli çocuklara yönelik bir eğitim politikası oluşturulamaması sorunu üzerine bir değerlendirme. 21. Yüzyılda Eğitim ve Toplum, Cilt 4 (12), 146-154. Publications.

KILDUFF, M., Tsai, W. (2007) Social networks and organizations. London: SAGE

KRACKHARDT, D. (1998). Simmelian ties: Super strong and sticky. Power and influence in organizations, (pp. 21-38). Thousand Oaks, CA: Sage.

KRACKHARDT, D., \& HANSON, J. R. (1993). Informal networks: The company behind the chart. Harvard Business Review, 71 (4), 104-113.

KURTDAȘ, M. Ç. (2012). Üstün yetenekliler ve üstün yeteneklilerin eğitiminde bilim ve sanat merkezleri (Malatya Bilim ve Sanat Merkezi Örneği). Düşünce - Yorum Sosyal Bilimler Araştırma Dergisi, Cilt 10 (2), 151 - 181.

MARSDEN, P.V. (2005). Recent developments in network measurement models and methods in social network analysis. Models and methods in social network analysis (pp. 8-30). New York: Cambridge University Pres.

MEHRA, A., KILDUFF, M. \& BRASS, D.J. (2001). The social networks of high and low self-monitors: Implications for workplace performance. Administrative Science Quarterly, 35, 121-46.

MEHRA A, DIXON AL, BRASS DJ, \& ROBERTSON B. (2006). The social network ties of group leaders: Implications for group performance and leader reputation. Organization Science, 17 (1), 64-79.

Millî Eğitim Bakanlığı (MEB). (2016). Bilim sanat merkezi yönergesi. Erişim tarihi: 24.12.2018,http://orgm.meb.gov.tr/meb iys dosyalar/2017 01/02031535 tebligler der gisi.pdf.

MOOLENAAR, N. M., SLEEGERS, P. J. C., \& DALY, A. J. (2012). Teaming up: Linkin collaboration networks, collective efficacy and student achievement. Teachig and Teacher Education, 28(2), 251-162. 
Zeynep Eren, "Bilim Sanat Merkezi Yöneticilerinin Bağlamsal Performansının Sosyal Ağ Analizi Yaklaşımı ile Değerlendirilmesi”, İstanbul Gelişim Üniversitesi Sosyal Bilimler Dergisi, 7 (1), Nisan 2020, ss. 50-73.

MOTOWIDLO, S.J., BORMAN, W. C., \& SCHMITT, M.J. (1997). A theory of some basic differences in task and contextual performance. Human Performance, 10 (2), 71-83. MOOLENAAR, N.M. (2012). A social network perspective on teacher collaboration in schools: Theory, methodology and applications. American Journal of Education. 119, 7-39.

MORGESON, F. P., REIDER, M.H., \& CAMPION, M.A. (2005). Selecting individuals in team settings. The importance of social skills, personality characteristics, and teamwork knowledge. Personnel Psychology, 58 (3), 583-612.

ORGAN, D. W. (1997). Towards an explication of morale: In search of the $m$ factor. Creating tomorrow's organizations.(pp.78-99) London,: John Wiley \& Sons.

ÖZTAȘ, N., ACAR, M. (2004). Ağbağ analizine giriș: Kavramlar ve yöntemler. Çăgdaş kamu yönetimi II. (s.s. 288-316), Ankara: Nobel Yayınevi.

PAINE, J.B.,\& ORGAN, D. W. (2000). The cultural matrix of organizational citizenship behavior: Some preliminary, conceptual and empirical observations. Human Resources Management Review, 10 (1), 45-59.

PENUEL, W. R., SUN, M., FRANK, K. A., \& GALLAGHER, H. A. (2012). Using social network analysis to study how collegial interactions can augment teacher learning from external professional development. American Journal of Education, 119(1), 103-136.

PODSAKOFF, PM. \& MACKENZIE SB. (1994). Organizational citizenship behavior and sales unit effectiveness. Journal of Marketing Research, 31 (3), 351-63.

REILLY, R.R. \& ARONSON, Z. H. (2012). Managing contextual performance Performance management: Putting research into action.(pp. 297-328). N.Y.: Wiley.

REAGANS R, ZUCKERMAN E, \& MCEVILY B. (2004). How to make the team: Social networks vs. demography as criteria for designing effective teams. Administrative Science Quarterly,49 (1), 01-13.

RENZULLI, J. S. (1978). What makes giftedness? Reexamining a definition. PhiDelta Kappan, 60, 180-184.

SARKAR A, FEINBERG SE, \& KRACKHARDT D. (2010). Predicting profitability using advice branch bank networks. Statistical Methodology, 7 (3), 429-444.

SCOTT, J. (2000). Social network analysis: A handbook. London: Sage

SARI, H., ÖĞÜLMÜŞ, K. (2014). Bilim ve sanat merkezlerinde (BİLSEM) karşılaşılan sorunların öğretmen ve öğrenci görüşleri açısından değerlendirilmesi. Uluslararası Türk Eğitim Bilimleri Dergisi, 2, 254-265.

SODA G, \& ZAHEER A. (2012). A network perspective on organizational architecture: Performance effects of the interplay of formal and informal organization. Strategic Management Journal, 33 (6), 751-771.

SCOTTER, J.R., \& MOTOWIDLO, S.J. (1996). Interpersonal facilitation and job dedication as separate facets of contextual performance. Journal of Applied Psychology, 81 (5), 525-531.

SHARMA V, \& JAIN S. (2014). A Scale for measuring organizational citizenship behavior in manufacturing sector. Pasific Business Review International, 6 (8), 57-62.

SHAW JD, DUFFY MK, JOHNSON JL, \& Lockhart DE. (2005). Turnover, social capital losses, and performance. Academy of Management Journal, 48 (4), 594-606.

SMITH CA, ORGAN DW \& NEAR JP. (1983). Organizational citizenship behavior: Its nature and antecedents. Journal of Applied Psychology, 68 (4), 653-63.

SÖZEN, C.H. (2012) Örgütsel ağlar. Örgüt kuramları. (ss. 301-326). İstanbul: Beta Basim

SPARROWE RT, LIDEN RC, WAYNE SJ, \& KRAIMER ML. (2001). Social networks and the performance of individuals and groups. Academy of Management Journal, 44 (2), 316-325. 
Zeynep Eren, "Bilim Sanat Merkezi Yöneticilerinin Bağlamsal Performansının Sosyal Ağ Analizi Yaklaşımı ile Değerlendirilmesi”, İstanbul Gelişim Üniversitesi Sosyal Bilimler Dergisi, 7 (1), Nisan 2020, ss. 50-73.

SPILLANE, J. P., KIM, C. M., \& FRANK, K. A. (2012). Instructional advice and information providing and receiving behavior in elementary schools: Exploring tie formation as a building block in social capital development. American Educational Research Journal, 49(6), 1112-1145.

STERNBERG, R. J., JARVIN, L., GRIGORENKO, E. L. (2011). Explorations in giftedness. New York: Cambridge University Press

ȘAHİN, F. (2012). Üstün yetenekli öğrencilerin öğretmenlerinin eğitimleri. Geleceğin mimarları üstün yetenekliler sempozyumu. Namık Kemal Üniversitesi Sağlık Hizmetleri Meslek Yüksekokulu. 27 Nisan 2012, Tekirdağ.

TURNIPSEED, D.L. \& MURKISON, E. (2000, December). A bi-cultural comparison of organization citizenship behavior: Does the OCB phenomenon transcend national culture? International Journal of Organizational Analysis, 8 (2):200-222. DOI:

10.1108/eb028917

Türkiye Büyük Millet Meclisi (TBMM). (5 Nisan 2012). Üstün yetenekli çocukların keșfi, eğitimleriyle ilgili sorunların tespiti ve ülkemizin gelișimine katkı sağlayacak etkin istihdamlarının sağlanması amacıyla kurulan meclis araștırması komisyonu raporu. Erişim tarihi: 11.10.2018, https://www.tbmm.gov.tr/arastirma komisyonlari/ustun yetenekli/docs/Kurulu\%C5 \%9F\%20Karar\%C4\%B1\%20Tutanaklar\%C4\%B1\%206.03.2012.pdf

TOMLINSON, C.A.,\& CALLAHAN C.M. (1992). Contributions of gifted education in a time of change. Gifted Child Quarterly, 36 (4), 183-189.

TSAI, W. (2001). Knowledge transfer in intra-organizational networks: Effects of network position and absorptive capacity on business unit innovation and performance. Academy of Management Journal, 44 (5), 996-1004.

WASSERMAN, S., GALASKIEWICZ, J. (1994). Advances in social network analysis: Research in the social and behavioral sciences. Sage Publications.

WELLMAN, B. (1988). Structural analysis: From method and metaphor to theory and substance. Social structures: A network approach, (pp. 19-61). Cambridge: Cambridge University Press.

WINEBRENNER, S. (2000). Gifted students need an education too. Educational Leadership, 58 (1), 52-56.

UĞURLU, Z. (2013). Eğitim örgütlerinin örgütsel ağbağ düzeneğindeki konumunun işbirliği düzeylerine etkisi: Sinop ili örneği. (Yayınlanmamış Doktora Tezi). Ankara Üniversitesi Eğitim Bilimleri Enstitüsü, Ankara.

UGURLU, Z. (2016a). Social network analysis of Farabi exchange program: Student mobility. Eurasian Journal of Educational Research, 65, 313-334.

UĞURLU, Z. (2016b). The effect of the position of educational organizations within the social network on their collaboration levels. Universal Journal of Educational Research, 4 (12A), 226-254.

YUMUŞ, A., \& TOPTAŞ, V. (2011). Bilim ve sanat merkezlerinin amacına uygun işleyişinin değerlendirilmesi. Mersin Üniversitesi Ĕ̆itim Fakültesi Dergisi, Cilt 7 (2),80-88.

\section{Summary}

Gifted students are trained in science Arts Center (BILLSEM) in Turkey. These institutions have been established since 1995 in order to support the development of gifted students in preschool, primary and secondary education in accordance with their interests and abilities in the Ministry of National Education (MEB). According to MEB 2018 statistics, approximately 2000 teachers work in these centers and 37500 gifted students are given education support in line with their abilities. All of gifted students in Turkey do not yet 
benefit from this training. In addition, there are various problems in the functioning of BILSEMs. In order to enable the education of gifted individuals to be carried out effectively, the learning environments, programs and teachers to be provided to these individuals need to be structured to address different and higher skills than normal students. The main task in this area is that those who make decisions about education fall into the managers in these institutions as well as those who determine strategies. The success of an organization cannot be distinguished from the performance of employees in the organization. Performance evaluation is a measure of the contribution of the employees in the organization to the organization and the actions and behaviors of the organization. The concept of performance is considered as a multidimensional concept consisting of task performance and contextual performance. Task performance is described as fixed tasks and responsibilities that allow a job to differentiate from other jobs, and is about completing the task. The behavior included in the task performance contributes to the technical basic abilities of the organizations. Contextual performance refers to activities that are not specific to the task or goal, but which make individuals, teams and organizations more effective and successful. In this study, the contextual performance of the senior managers of the Science Art Centers (BILSEM) was analyzed by means of the professional support network patterns. In several provinces and regions qualitative and social network analysis methods to research conducted by mixed research methods being used together across Turkey gave support worker 30 senior manager. The data of the study were collected online in 2018 with semi-structured interview form. In the research, it has been asked about which other colleagues of the managers to support each other in order to improve their work and to get support from them for their support and to develop professional support network patterns and analyze them with UCINET 6.0 software. According to the findings of the research, the professional support networks of the 30 managers are composed of 68 actors and 113 links. 25\% of the maximum connection is realized. Although they are distant from each other in different geographical regions and there is a professional support relationship between them, it is found that the seniority variable is more valuable in terms of getting professional support for the participants according to the educational variable. The findings of this study show that the use of social network analysis to measure contextual performance will lead to a new breakthrough. Recent developments in the field of organization and management science have shown that the intense change experienced in the 21st century transforms the working relations in organizations as well as in many issues. In this process, it is clear that the psychological convention specific to the industrial age would be insufficient to explain the organizational relations of this new complex, fast-changing, multi-focused, dynamic information and communication age. Social network analysis fills the gap in this matter with the analysis approaches it presents. According to the research findings, the following suggestions can be made: In performance evaluation, rewarding systems of actors providing support to other colleagues can be established in order to evaluate the performance of the task as well as the performance of the context. Awarding managers who contribute to other colleagues will help increase the number of actors who contribute to more efficient and efficient work within the network. Social network analysis can bring a new perspective as a complement to traditional approaches in human resource practices and performance evaluation within these applications. However, the number of studies in Turkey on this issue is rather limited. Researches with this approach can be expanded. As the number of work done increases, the possibility of making network comparisons will increase. This research can be carried out by ensuring the participation of all BILSEMs, and the network can be monitored by either network comparable or longitudinal research. In this way, the decisions needed for the development of BILSEMs can be taken based on data. 